\title{
The Use of Algae and Fungi for Removal of Pharmaceuticals by Bioremediation and Biosorption Processes: A Review
}

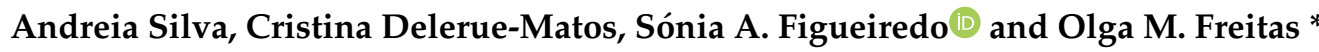 \\ REQUIMTE/LAQV, Instituto Superior de Engenharia do Porto, Rua Dr. António Bernardino de Almeida 431, \\ 4200-072 Porto, Portugal \\ * Correspondence: omf@isep.ipp.pt
}

Received: 3 July 2019; Accepted: 25 July 2019; Published: 27 July 2019

\begin{abstract}
The occurrence and fate of pharmaceuticals in the aquatic environment is recognized as one of the emerging issues in environmental chemistry. Conventional wastewater treatment plants (WWTPs) are not designed to remove pharmaceuticals (and their metabolites) from domestic wastewaters. The treatability of pharmaceutical compounds in WWTPs varies considerably depending on the type of compound since their biodegradability can differ significantly. As a consequence, they may reach the aquatic environment, directly or by leaching of the sludge produced by these facilities. Currently, the technologies under research for the removal of pharmaceuticals, namely membrane technologies and advanced oxidation processes, have high operation costs related to energy and chemical consumption. When chemical reactions are involved, other aspects to consider include the formation of harmful reaction by-products and the management of the toxic sludge produced. Research is needed in order to develop economic and sustainable treatment processes, such as bioremediation and biosorption. The use of low-cost materials, such as biological matrices (e.g., algae and fungi), has advantages such as low capital investment, easy operation, low operation costs, and the non-formation of degradation by-products. An extensive review of existing research on this subject is presented.
\end{abstract}

Keywords: algae; fungi; bioremediation; biosorption; removal of pharmaceuticals; wastewater

\section{Introduction}

The growth of world population, the promotion of health and better living conditions, and the rise of average life expectancy were accompanied by an increase in the consumption of pharmaceuticals, which are excreted in their original form or as metabolites and collected by the sewage system of urban wastewaters; they are not completely removed by wastewater treatment plants (WWTPs). Their occurrence in the aquatic environment is creating polluting pressure on aquatic ecosystems and is recognized as one of the emerging problems in the last decade [1]. The development of analytical techniques (such as gas chromatography mass spectrometry and liquid chromatography mass spectrometry) enabled the detection and quantification of a broad range of pharmaceuticals (and their metabolites) in environmental matrices [2]. Although they occur at extremely low levels (ranging from $\mu \mathrm{g} \cdot \mathrm{L}^{-1}$ to $\mathrm{ng} \cdot \mathrm{L}^{-1}$ or even lower), it is known that their presence in the environment is a potential hazard to public health [3-6].

The release of pharmaceuticals into the aquatic environment is not yet subject to regulation. In Europe, the "Water Framework Directive 2000/60/EC" introduced a strategy for water protection [7]. However, since the water situation in the several European Union (EU) countries was, and still is, different, it was necessary to proceed with adjustments to the original "Water Framework Directive". 
In fact, one year after its publication, Decision 2455/2001/EC of the European Parliament and of the Council of 20 November 2001 established that each European Union member state should create, until 2009, a program of environmental protection measures for each of its hydrographic regions. A list of 33 priority substances in the field of water policy was also established, which includes pharmaceuticals. The revision and update of this list is done at least every four years, this may lead to the inclusion of new priority compounds, or removal, depending on the level of risk they pose [8]. Later, the "Directive on Environmental Quality Standards" (Directive 2008/105/EC) amended some environmental quality standards in the field of water policy and also established 11 new substances to be identified as priority substances or priority hazardous substances [9]. The Directive 2013/39/EU and Implementing Decision 2015/495 incorporated new substances, totalizing 45, implementing the first so-called watchlist. A few pharmaceuticals (diclofenac, erythromycin, clarithromycin, and azithromycin), as well as synthetic and natural hormones (estrone, $17 \beta$-estradiol, and $17 \alpha$-ethinylestradiol), were included, and they should be carefully monitored by the Member States in order to set their environmental quality standards $[10,11]$. In its last review, five substances or groups of substances were removed, among them diclofenac, and three new substances were included, among them amoxicillin and ciprofloxacin. This is consistent with the European One Health Action Plan against Antimicrobial Resistance, which supports the use of the watchlist to improve knowledge and to evaluate the risks to human and animal health posed by the presence of antimicrobials in the environment. This review resulted in the publication of the second watchlist in 2018 (of the Commission Implementing Decision 2018/840 [12]. Also, in the United States, the Environmental Protection Agency (EPA) included 12 pharmaceuticals, personal care products, and endocrine disrupting compounds in a list in order to evaluate their related occurrence and safety risks. Therefore, is expected that, in the near future, legal limits will be established for the concentration of pharmaceuticals in WWTP discharges.

Indeed, pharmaceuticals are introduced into the environment (Figure 1) mainly through the discharge of treated effluents from conventional WWTPs, via domestic and hospital wastewaters, directly or by leaching of the sludge produced by these facilities, or through discharges of the pharmaceutical industry [13-15], as well as veterinary facilities where pharmaceuticals are widely used in livestock production for disease prevention and growth promotion [16-18].

The most frequently detected classes of pharmaceuticals in wastewaters are antibiotics, antiepileptics, antiphlogistics, $X$-ray contrast media, lipid-regulators, $\beta$-blockers, and tranquillizers [19]. Most of these compounds have high solubility, low hydrophobicity, and often negative charge at neutral $\mathrm{pH}$ (acidic compounds); these properties add more difficulties to their treatment [20]. WWTPs were not specifically designed to completely remove pharmaceuticals [21,22]. Removal efficiencies can vary from negligible to $100 \%$ depending on the compound [23]. The majority of compounds are removed in a percentage of less than $50 \%$, which is related to the structure of the compounds [20]. Many physico-chemical and biological treatments were tested by WWTPs, but none of them are able to efficiently remove them [24]. Tertiary treatments, such as membrane technologies and advanced oxidation processes, usually play a more active role in the removal of these micropollutants than primary and secondary treatments $[5,25]$. However, they have many drawbacks in terms of energy requirement, large use of chemicals, and formation of undesired and harmful by-products [26]. To overcome these drawbacks, the scientific community focused its attention on the development of eco-friendly, economically viable and comparatively less expensive technologies [27]. Biological tertiary treatments of wastewaters are efficient, less expensive, and more eco-friendly than other technologies. The use of certain microorganisms gained importance in applied environmental microbiology. Fungi and algae-based treatments were pointed out as promising technologies for the remediation of pharmaceuticals. In this article, special attention is given to studies addressing pharmaceutical removal with fungi and algae via bioremediation and/or biosorption mechanisms (Figure 2). 


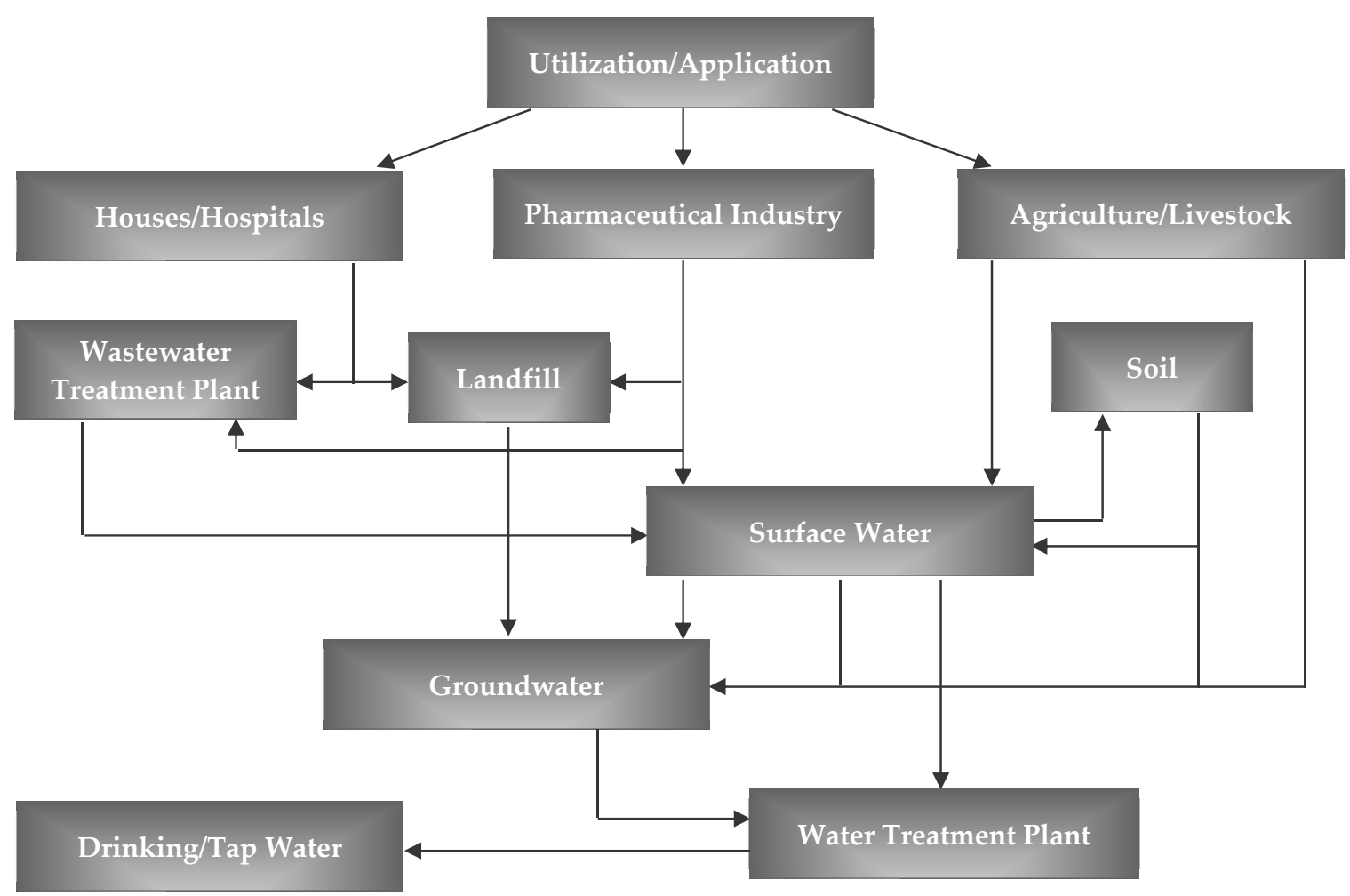

Figure 1. Pathways of pharmaceutical introduction into the environment.

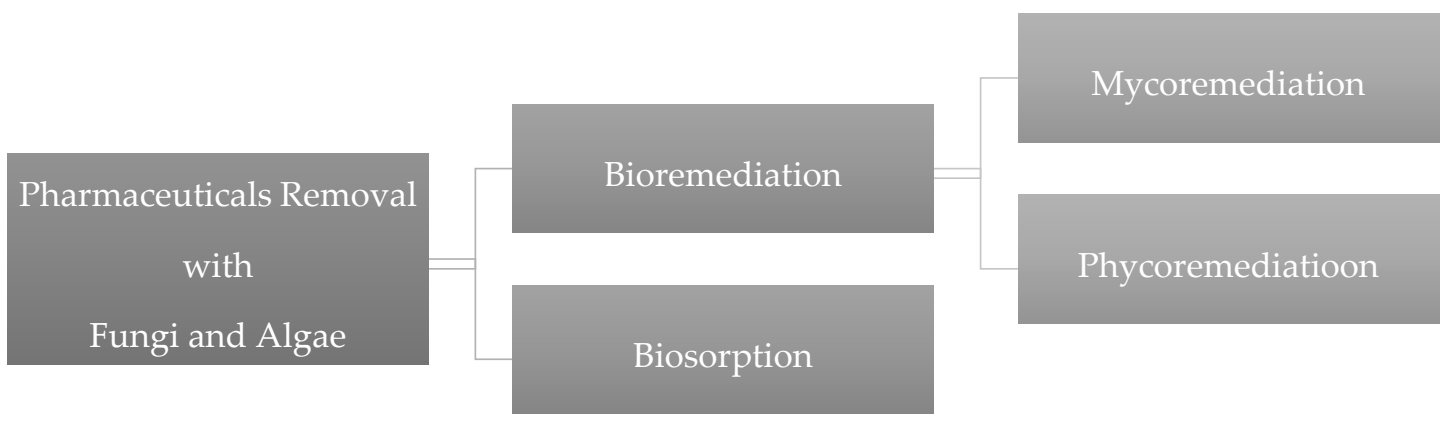

Figure 2. Mechanisms of pharmaceutical removal with fungi and algae.

\section{Bioremediation}

Bioremediation is a biological treatment that involves the use of microorganisms and their enzymes to convert recalcitrant and xenobiotic contaminants to less toxic forms and, therefore, short lifetimes in the environment or even their complete mineralization (the end-products are essentially carbon dioxide and water) [28]. Bioremediation of organic compounds was studied in more detail at the laboratory level, with the metabolic pathways of degradation known for some pharmaceutical compounds [29,30]. The process is influenced by environmental, physical, and chemical factors, namely, the stereochemistry, toxicity, and concentration of the contaminant, efficiency of the microbial strain, conditions during degradation (e.g., $\mathrm{pH}$ and temperature), retention time, presence of other compounds, and their concentration [31]. Some of bioremediation's advantages are as follows: it is accepted as a safe process, transforms pollutants instead of simply moving them from one medium to another [32], and presents lower costs when compared to the other technologies [33]. Although bioremediation proves to be a promising choice, research is needed to overcome some drawbacks of the process, which are the incomplete transformation, the limitation to biodegradable compounds, and the requirement of the selection and use of different microorganisms with specific metabolism for the different pollutants. Some of these disadvantages can be overcome through the use of genetically modified microorganisms [34]. 


\subsection{Mycoremediation}

Fungi ("mikes" from Greek) are eukaryotic organisms that include microorganisms such as molds, yeasts, and mushrooms. Some fungi are chemoheterotrophic organisms, being parasitic or saprophytic. Some are unicellular, and many are filamentous and have cell walls. The kingdom Fungi includes phyla Chytridiomycota (the chytrids), Zygomycota (the conjugated fungi), Ascomycota (the sac fungi), Basidiomycota (the club fungi), Deuteromycota (the imperfect fungi), and Glomeromycota. This classification was established according to their mode of sexual reproduction or using molecular data [35]. Fungi were efficiently used to treat water samples contaminated with micropollutants [36,37], pharmaceuticals in particular (Table 1). They are long recognized for their abilities to transform a broad range of recalcitrant compounds using nonspecific intracellular and extracellular oxidative enzymes [38-40]. The physiology and colonization strategy of mycelial fungi allows them to more easily withstand sudden changes in $\mathrm{pH}$ or humidity, as well as to degrade more efficiently complex organic compounds [41], although they are limited by a long growth cycle and spore formation [42].

\subsubsection{Treatment Systems}

Fungal reactors, also termed mycoreactors, can be suspended growth (such as slurry reactors) or immobilized systems (such as trickling filters, rotating biological contactors, upflow fixed-film reactors, and fluidized-bed reactors); these latter allow a fast biodegradation. Mycoreactors can be operated in batch, semi-batch, sequencing batch, or continuous mode, like other biological reactors. They can also be operated under aerobic or anaerobic conditions. Mycoreactors for submerged growth include stirred tanks, packed bed, bubble column, and air-lift [43], with stirred tanks as the most common, where the culture medium is agitated mechanically, providing a good fluid mixture and a good oxygenation. However, they have disadvantages such as the stress generated by the agitation, their impracticality for certain microorganisms, and the high energy consumption for high agitation speeds. Air-lifts are pneumatically agitated mycoreactors very similar to the stirred tanks; however, the fluid mixing is done by injecting air or compressed gas into the base of the bioreactor. This bioreactor is usually cylindrical so that the air bubbles remain as long as possible in the fluid. Compared with stirred tank, air-lifts have worse mixing rates; however, they generate less stress to the microorganisms [44,45]. Pellet-forming fungi, which are easier to recover at the end of the treatment, are cultivated in aerated fluidized-bed or suspended air-lift loop reactors [43].

\subsubsection{Mechanisms of Removal}

White-rot fungi (WRF), in particular, belong to the Basidiomycota phylum, whose potential was explored in several studies about the removal of pharmaceuticals (Table 1) [46-72]. These strains are filamentous wood-degrading fungi, ubiquitous in nature, able to mineralize lignin efficiently. The name white rot derives from the bleached appearance of the wood attacked by these fungi due to the removal of the dark-colored lignin. The same mechanism that gives these fungi the potential to degrade lignin also allows them to degrade a wide variety of recalcitrant pollutants, such as pharmaceuticals, making them promising and attractive microorganisms for wastewater bioremediation. They are able to mineralize a wide variety of pollutants since their enzymatic system is non-specific, non-stereoselective, and based on free-radical levels [73]. Pollutant degradation (Figure 3) seems to involve either an intracellular enzymatic system (i.e., cytochrome P450 system) or an extracellular enzymatic system (mainly lignin peroxidase, manganese peroxidase, laccase, and versatile peroxidase) [73,74]. Peroxidases are secreted during secondary metabolism of WRF in the presence of nitrogen, carbon, or sulfur limitations, while laccases are glycosylated multicopper oxidoreductases that are produced during primary metabolism [75]. Peroxidases generally show higher redox potential than laccases; however, peroxidases suffer deactivation in the presence of hydrogen peroxide while laccases do not [76-78]; laccase performance seems to be affected by the presence of chlorine ions forms [79]. Lignin peroxidase catalyzes the one-electron oxidation of various aromatic 
compounds, with subsequent formation of aryl cation radicals which are decomposed spontaneously by various pathways. Manganese peroxidase catalyzes the oxidation of $\mathrm{Mn}^{2+}$ to $\mathrm{Mn}^{3+}$, which in turn can cause oxidation of several phenolic substrates [80]. Fungal laccases were reported in several studies since these enzymes have wide substrate ranges and use only oxygen as the final electron receptor, producing water as the only by-product [65,81-103]. In many cases, preference was given to the use of isolated enzymes (enzymatic bioremediation) instead of the use of fungi biomass in order to reduce the time of treatment, to avoid the lag phase of fungal growth, to reduce sludge production, and to facilitate process control [39]. It was found that Phanerochaete chrysosporium, a major WRF, does not have laccase genes [104]. Trametes versicolor is a WRF frequently cited in the literature that was shown to be effective in the removal of different pharmaceuticals (Table 1) [46,47,50-55,57-62,72].

For example, strains of Trametes versicolor, Irpex lacteus, Ganoderma lucidum, and Phanerochaete chrysosporium were simultaneously tested in the removal of ibuprofen, clofibric acid, and carbamazepine. The results suggested that clofibric acid and carbamazepine degradation occurred intracellularly by the cytochrome P450 system of Trametes versicolor [46]. Using the same fungus, Nguyen et al. [54] compared the removal of trace organic contaminants (including pharmaceuticals and steroid hormones) by alive, intracellular enzyme-inhibited and chemically inactivated whole-cell preparations, and a fungal extracellular enzyme extract, predominantly laccase. The low degradation of some hydrophobic compounds by the extracellular extract, and the impact of intracellular cytochrome P450 system inhibition on the degradation of some trace organic contaminants by the whole-cell culture indicated the importance of extracellular enzyme-independent catalytic pathways. Rodriguez-Rodriguez et al. [49] studied the removal of sulfonamides sulfapyridine and sulfathiazole by Trametes versicolor. Complete degradation was achieved for both compounds, although a longer period of time was needed to completely remove sulfathiazole when compared to sulfapyridine. In order to determine the effect of cytochrome P450 inhibitors, piperonyl butoxide or 1-aminobenzotriazole was added in the experiments performed. The results showed that sulfathiazole degradation was partially suppressed, while no additional effect was observed for sulfapyridine. In another study, Trametes versicolor was able to degrade carbamazepine in aqueous medium in an air-pulsed fluidized bioreactor in batch and continuous mode. In batch mode, carbamazepine concentration decreased $96 \%$, while, in continuous mode, carbamazepine concentration decreased $54 \%$. In this case, it was not possible to establish a correlation between extracellular laccase activity and carbamazepine degradation, since laccase and manganese peroxidase levels were negligible during the initial period, which may indicate that these enzymes were involved in an early stage of carbamazepine removal [47].

Rodarte-Moralez et al. [48] studied the removal of six pharmaceuticals (citalopram, sulfamethoxazole, diclofenac, ibuprofen, naproxen, and carbamazepine) from an initial mixture by three other WRF strains, Bjerkandera sp. R1, Bjerkandera adusta, and Phanerochaete chrysosporium, and also confirmed their enzymatic activity, particularly manganese peroxidase. An intense enzymatic activity was also detected during the individual degradation of $17 \alpha$-ethinylestradiol and carbamazepine by ligninolytic fungi strains Pleurotus sp. P1, Pleurotus ostreatus BS, and a (unidentified) basidiomycete strain BNI. During $17 \alpha$-ethinylestradiol degradation by Pleurotus sp. P1, laccase and manganese peroxidase activity was detected, while, during carbamazepine degradation by strain BNI, laccase, manganese peroxidase, and lignin peroxidase activity was detected [68].

Nguyen et al. [51,54] revealed in their studies that the enzymatic performance of laccase, in particular, can be enhanced by the addition of mediators. These authors studied the effect of continuous dosing of a mediator (1-hydroxybenzotriazole) in the removal of trace organic contaminants, including pharmaceuticals, from an initial complex mixture by Trametes versicolor. Becker et al. [63] studied the removal of 38 antibiotics (majority non-phenolic) from a mixture using immobilized laccase (Trametes versicolor), in an enzymatic membrane reactor, with or without the addition of syringaldehyde as a mediator. Thirty-two out of 38 antibiotics were removed by up to $50 \%$ when a mediator was used. In contrast, no significant removal was observed in experiments applied without a mediator. 
Indeed, mediators can be oxidized by laccase to free radicals, which in turn can oxidize pollutants less specifically, increasing the variety of pollutants potentially degraded by these enzymes [105].

Synthetic and natural laccase mediators were used in enzymatic studies. Synthetic mediators include 2,2'-azino-bis(3-ethylbenzothiazoline-6sulfonate) and 1-hydroxybenzotriazole, while natural phenolic mediators include syringaldehyde and acetosyringone. Natural mediators are more economically feasible and more environmentally friendly than artificial mediators [106]. Each mediator has a specific catalytic mechanism $[107,108]$. The effect of a mediator depends on the radicals formed, the mediator recyclability, and the laccase stability in the mediator's presence $[106,107,109,110]$. Despite the proven increase in efficiency, mediators incur additional costs, and can cause toxicity $[63,111]$ and laccase inactivation [112-114]. For example, Becker et al. [63] observed that, although the addition of syringaldehyde enhanced the removal of antibiotics, unspecific toxicity was also induced.

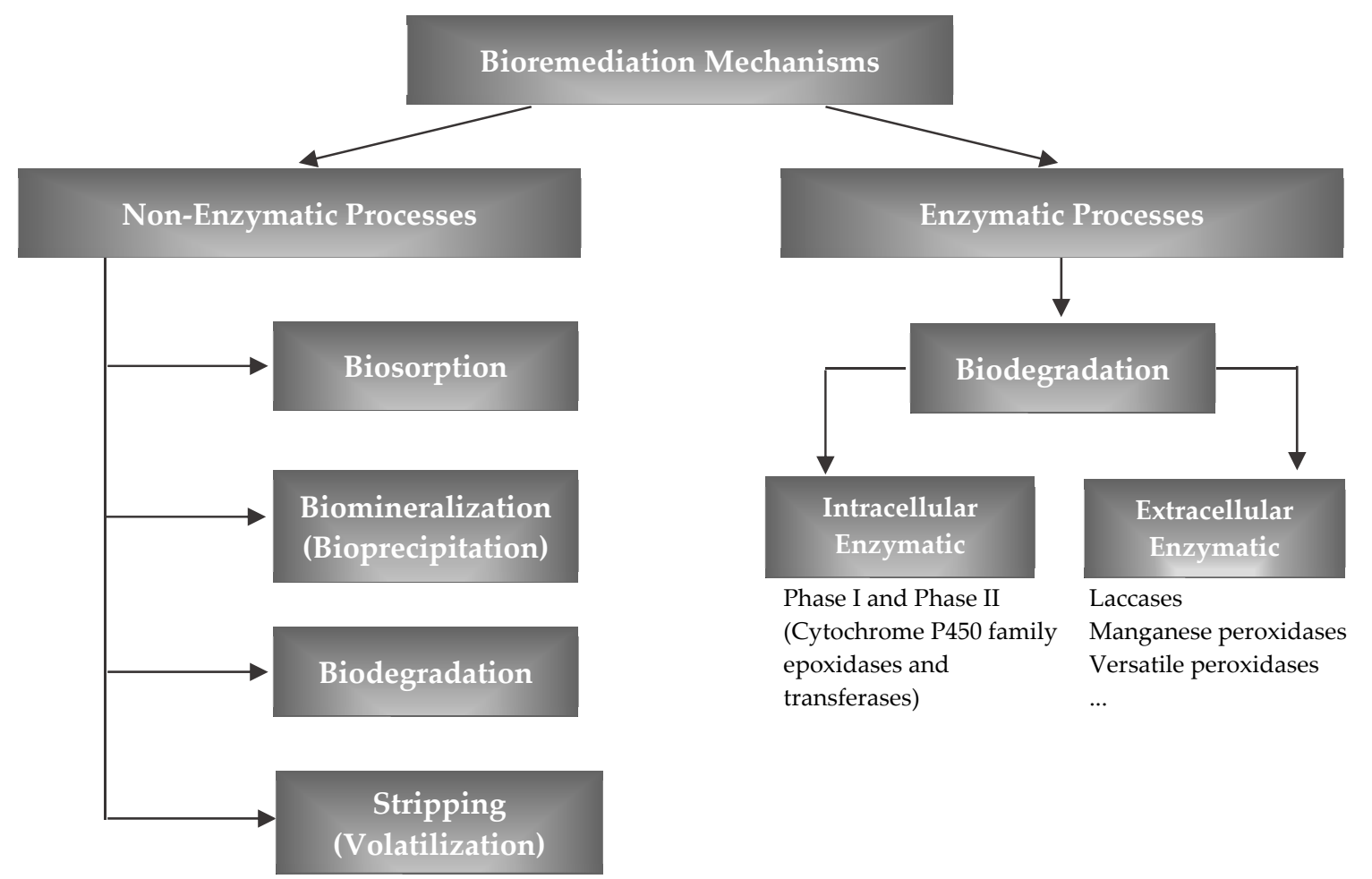

Figure 3. Fungi and algae strategies to counteract pharmaceuticals.

\subsubsection{Factors That Influence the Degradation Capability}

Fungi are able to degrade very low or non-detectable concentrations levels [73] and withstand a wide range of $\mathrm{pH}$, further enhancing their degradation capability [115]. Nevertheless, mycoremediaton requires specific and controlled conditions in order to maintain a durable and efficient process. Fungi oxidative metabolism can be strongly affected by the presence of nutrients, $\mathrm{pH}$, immobilization on different supports, and agitation/static growth conditions [31]. Zhang and Geißen [116] tested the degradation of carbamazepine and diclofenac by lignin peroxidase produced by WRF Phanerochaete chrysosporium in various conditions. It was found that lignin peroxidase completely degraded diclofenac at $\mathrm{pH} 3.0-4.5$ and 3-24 mg. $\mathrm{L}^{-1} \mathrm{H}_{2} \mathrm{O}_{2}$, while the degradation efficiency of carbamazepine was mostly below $10 \%$. The addition of veratryl alcohol and the high temperature $\left(30^{\circ} \mathrm{C}\right)$ did not enhance the carbamazepine degradation. In another study, the removal of carbamazepine by Phanerochaete chrysosporium in a plate bioreactor operated in batch and continuous systems showed that carbamazepine removal depends on a sufficient nutrient supply. Carbamazepine concentration decreased about $80 \%$ when a diluted synthetic nutrient medium was fed to the reactor and decreased about $60 \%$ when a real effluent with additional glucose and nitrogen was fed to the reactor, after 100 days of incubation [49]. 
By opposition, $17 \alpha$-ethinylestradiol was completely degraded by Pleurotus sp. P1, Pleurotus ostreatus BS, and a (unidentified) basidiomycete strain BNI, in the presence or absence of another carbon source [68].

Becker et al. [57] showed that the degradation of hormones by laccases is feasible even at very low enzyme concentrations, and that immobilized enzymes displayed better removal performance compared to the free enzyme. Indeed, enzyme immobilization provides a more suitable environment for enzymes and may result in an increasing enzyme stability concerning $\mathrm{pH}$, temperature, and storage time. Efficient use of immobilized cells requires, however, control of physiological/metabolic changes occurring either during the immobilization process or during the biotransformation phase. Enzyme immobilization can be done with irreversible methods (e.g., covalent binding and entrapment) or reversible methods (e.g., adsorption, ionic binding, affinity binding, chelation, and disulfide bonds). The selection of the immobilization method is based on technical-economic criteria. Since cost is a preponderant parameter, the simplest ones are usually used [117].

An eventual contamination with bacteria can negatively affect the efficiency since it can generate competition for the substrate, damage fungi mycelium, disrupt biomass growth, and destabilize fungal activity $[118,119]$. To avoid bacterial contamination, some strategies can be implemented. In the biological treatment system, the $\mathrm{pH}$ has great influence, since it acts in the development and selection of the microorganisms. Therefore, it is convenient to operate under acidic conditions, since the optimum $\mathrm{pH}$ for fungi growth is lower than the optimum $\mathrm{pH}$ for most bacteria. Other possible strategies include pretreatment by coagulation-flocculation of wastewater, since a reduction of the initial bacterial count usually occurs; coupling the bioreactor with a micro-screen, which allows the retention of fungal biomass and, simultaneously, the washout of bacteria with effluent; the use of disinfectant agents that allow the selection and/or inactivation of bacteria; the immobilization of fungal strains in different carriers; and the periodic replacement of fungal biomass [118].

Sterility conditions do not appear to be a mandatory requirement to apply Trametes versicolor in pharmaceutical removal. The studies performed showed that this microorganism was able to partially or completely remove pharmaceuticals either under sterile or non-sterile conditions [50,52].

\subsubsection{Concluding Remarks and Future Challenges for Mycoremediation}

In general, studies indicate a significant reduction in wastewater toxicity after treatment. Some fungi strains found in the literature $[46,47,50,52,53,61,120]$ proved to be effective in pharmaceutical removal (Table 1). Final products were reported to be less toxic or more biodegradable than the parent compounds, which emphasizes the potential of fungi as remedial agents.

Genetic tools can represent an essential step to improve fungi performance and overcome some limitations associated with the process. The sequencing of fungi genomes will allow the development of new genetic techniques to improve metabolic and adaptive processes, and consequently achieve efficient bioremediation [121]. To date, efforts met limited success, and there is still a long way to go before the introduction of modified fungi in remediation processes. The first complete eukaryotic genome belongs to the yeast Saccharomyces cerevisiae [122]. Several projects released information about the genome sequences of fungi Aspergillus nidulans, Aspergillus fumigatus, Neurospora crassa, and Coprinus cinereus [123]. The thirty-million-base-pair genome of WRF Phanerochaete chrysosporium strain RP78 was sequenced using a whole-genome shotgun approach [124]. The genome revealed genes encoding oxidases, peroxidases, and hydrolytic enzymes involved in wood decay, which opens new horizons related to the process of biodegradation of organic pollutants and pharmaceuticals in particular [125]. However, the risks involved in the use of genetically modified fungi, their impact on the environment and human health, and existing legal limitations must be considered [126].

\subsection{Phycoremediation}

Algae ("phyco" from Greek) include prokaryotic organisms (cyanobacteria) and eukaryotic organisms (all the algae species) that contain chlorophyll and carry out oxygenic photosynthesis. Although most algae are of microscopic size and, hence, are clearly microorganisms (microalgae), 
several forms are macroscopic (macroalgae) grow to over $30 \mathrm{~m}$ in length. Algae are either unicellular or colonial. When the cells are arranged end to end, the alga is said to be in filamentous form [127]. According to Ruggiero et al. [128], algae can be classified according to the pigments they possess. Algae color differences arise due to the proportions of different auxiliary photosynthetic pigments present in addition to the green chlorophylls. Chlorophyta (the green algae) and Euglenophyta (the euglenoids) are green since chlorophyll $a$ is dominant. If carotenoids are dominant in the algae, they give them a golden-brown color, such as Chrysophyta, whose chloroplasts contain chlorophylls $a_{1} c_{1}$, and $c_{2}$, fucoxanthin, and $\beta$-carotene, which are the carotenoids responsible for the golden-brown color. Dinophyta (the dinoflagellates), have a reddish, greenish, or brown appearance due to chlorophylls $a$ and $c_{2}$ and carotenoids. Rhodophyta (the red algae) have chlorophylls $a$ and $d$, phycobiliproteins, and floridean starch as storage products accumulated in the cytoplasm outside the chloroplast. In Phaeophyta (the brown algae), color results from the dominance of fucoxanthin over chlorophylls $a$, $c_{1}$, and $c_{2}$.

Algae are highly adaptive microorganisms and can grow autotrophically, heterotrophically, or mixotrophically. They can grow in very harsh environmental conditions, such as low nutrient levels, and extreme $\mathrm{pH}$ and temperature, which is an advantage over some species of fungi [129]. Unlike strictly heterotrophic microorganisms, the decrease in nutrient concentration does not limit the growth of algae [130]. Microalgae can acclimatize to changes in temperature, salinity, light, and nutrient availability, which allows the improvement of their tolerance and biodegradation capacity. This adaptation mechanism to extreme conditions is explained by genetic changes caused by spontaneous mutation or physiological adaptation [131,132]. Xiong et al. [133] evaluated the biodegradation capability of Chlorella vulgaris after acclimation with multiple exposures to levofloxacin and an increase in salinity. Results showed that levofloxacin biodegradation was significantly improved after acclimation.

The characteristics of domestic wastewaters is usually suitable for the cultivation of microalgae, since wastewaters represent a source of nutrients. From an environmental perspective, photosynthetic microalgae are fascinating since they can sequester atmospheric carbon dioxide for their own growth, contributing to the mitigation of this pollutant. In a properly controlled process, the association of microalgae with bacteria may result in a very synergistic relationship; microalgae provide oxygen while bacteria release carbon dioxide, which allows a significant reduction of oxygen needs in the treatment process [134-137]. In addition, microalgae treatment supplies an environment that increases the mortality of pathogenic organisms due to the $\mathrm{pH}$ elevation [138]. A win-win situation of using microalgae in wastewater bioremediation offers a tertiary biotreatment of wastewater coupled with the production of potentially valuable biomass as a bioresource for biofuel or high-value by-products [139].

\subsubsection{Treatment Systems}

From the economic point of view, open systems are preferred for wastewater phycoremediation. Operational factors that influence algae growth are essentially mixing, dilution rate, and depth [140]. Open ponds are the most usual for microalgae cultivation since they require lower investment costs and operational capital. Commercially, algae cultivation is mainly performed on open channels stirred with a paddlewheel (raceway), since they are less expensive and easier to construct and operate. There is, however, a high risk of contamination and low productivity due to a poor mixing regime and light penetration, and also due to the difficulty of controlling the operating conditions [141]. Facultative, maturation, and high-rate algal ponds are the most used open systems for wastewater treatment, with the first two being the most used. The major differences between them are the depth and origin of the influent. The major constraints include poor light utilization by the cells, water loss due to evaporation, diffusion of carbon dioxide to the atmosphere, temperature fluctuations, inefficient stirring, and large space requirements for microorganism growth [142]. Open systems usually operate under long hydraulic retention time (between eight and 14 days) in order to consume carbon dioxide 
during the day (photosynthesis) and provide oxygen for aerobic biodegradation. Sunlight intensity influences photosynthetic activity, leading to $\mathrm{pH}$ and dissolved oxygen variations [143-145].

Closed systems were designed to overcome the problems associated with open systems. Unlike open systems, closed systems allow greater control of the process; however, they are expensive to install and to maintain [146]. Closed systems are most suitable for pure algae strains, and their design must be carefully optimized for each individual strain according to its unique physiological and growth characteristics. These systems avoid losses by evaporation, and reduce the contamination risk and the losses of carbon dioxide to the atmosphere [147]. Closed systems, which are mostly photobioreactors, exist in various design configurations (e.g., horizontal or serpentine tube, flat-plate, bubble column, air-lift column, and stirred tank). Flat-plate photobioreactors have space constraints, and tubular photobioreactors have design limitations. Column photobioreactors are the most efficient, which provide efficient mixing, the highest volumetric mass transfer rates, and the best controllable growth conditions. Some difficulties arise with scale-up caused by inhomogeneous distribution of light inside the culture. The productivity is negatively affected by central, light-deprived zones [148]; therefore, to facilitate penetration of light, photobioreactors are made of glass, transparent plastic material, or sturdy polythene.

Among all the drawbacks associated with phycoremediation, harvesting is one of the most challenging processes integrated in the removal treatment. The harvesting process may account for $30 \%$ of total microalgae biomass production cost. Several factors affect the harvesting, such as microalgae strain and operational parameters (hydraulic and solid retention times) [149]. Harvesting technologies may involve one or more steps, and different physical (e.g., centrifugation, gravity sedimentation, filtration, and dissolved air flotation), chemical (e.g., chemoflocculation), and biological (e.g., bioflocculation and microalgae immobilization) processes.

Most of these processes are limited by high costs, long processing times, high energy consumption, and low recovery $[150,151]$. The choice of the harvesting method depends on the microalgae characteristics, such as the density and size of algal cells, as well as the product derived from the algal biomass [152].

The most environmentally friendly method is bioflocculation as it involves formation of extracellular biopolymers that help natural flocculation of small particles $[150,151]$. Some microalgae species flocculate more readily than others, and these microalgae can be mixed with other species to induce flocculation $[153,154]$. However, this method may be not efficient due to the small size of microalgae cells and their fast growth. Further research is required to understand the underlying mechanism associated with this process.

New technologies were considered, namely, the addition of other microorganisms, such as bacteria and some fungal species, to the microalgae culture [135]. In the first case, microalgae and bacteria may form flocs that settle more easily than single microalgae. It is necessary to add an extra organic substrate to allow bacteria growth [135], which can be provided by using wastewater. The presence of an organic carbon source in wastewater allows both organisms to thrive together $[155,156]$. The main disadvantages are the influence of dominant microalgae species and the variability of wastewaters [135]. In the second case, some filamentous fungi can pelletize, entrapping the microalgae cells, which facilitates the harvest by simple sieve filtration or sedimentation in most cases [157]. It is not necessary to add an extra sugar to allow fungi growth [158]. Co-pelletization efficiency seems to depend both on fungi and microalgae strains and on culture conditions (in particular on the $\mathrm{pH}$ value). The choice of fungi strains will be the key issue since it determines the overall pelletization efficiency and, therefore, can have a direct impact on the subsequent processes. Since this method does not require the addition of chemicals or inputs of energy, it may offer a solution to two of the major problems of harvesting processes, the high cost and high energy consumption [159]. The competition of nutrients between fungi and microalgae is believed to occur mostly in heterotrophic conditions, since microalgae need external carbon sources to support their growth, or in autotrophic conditions, when other nutrients, such as organic nitrogen, are limited. In this context, neither fungi nor microalgae cells will reach their maximum growth compared with their growth in individual pure cultures [160]. It is not clear if co-culturing fungi affects the growth 
and nutrient assimilation of microalgae [161]. It is also unclear how the use of fungi for pelletization is fundamentally different or superior to the use of bacteria for bioflocculation [161,162].

\subsubsection{Mechanisms of Removal}

Studies about the removal of emerging contaminants (such as pharmaceuticals) with algae are limited; therefore, the mechanisms involved are not yet very clear (Table 1) [163]. The possible mechanisms involved in algal-bacterial systems (Figure 3) seems to be biodegradation, biomineralization (bioprecipitation), biosorption (cell adsorption and/or bioaccumulation), stripping (volatilization), and photodegradation, due to the effect of light [163-165]. However, volatilization can be considered negligible for most pharmaceuticals, because of their low Henry's constant values [166]. The bioaccumulation of pharmaceuticals in algae cells can induce the generation of reactive oxygen species, free radicals (e.g., $\mathrm{O}_{2} \bullet$ - superoxide radicals, $\mathrm{OH}^{\bullet}$ - hydroxyl radical, $\mathrm{HO}_{2} \bullet$ - perhydroxy radical, and $\mathrm{RO}^{\bullet}$-alkoxy radicals) and nonradical forms (e.g., $\mathrm{H}_{2} \mathrm{O}_{2}$-hydrogen peroxide and ${ }^{1} \mathrm{O}_{2}$ - singlet oxygen). At normal levels, these species act as essential signaling molecules to control cellular metabolism; however, at excess levels, these species can cause severe damage to cellular components and an increased rate of mutagenesis that ultimately leads to programmed cell death [167]. Such as for fungi, pollutant degradation by algae seems to involve intracellular and extracellular enzymatic systems (Figure 3). Intracellular degradation of pharmaceuticals involves a phase I enzyme (cytochrome P450) [163,168-173] and a phase II enzyme (e.g., glutathione-S-transferases) [171]. Extracellular degradation of pharmaceuticals involves the excretion of various extracellular polymeric substances, such as polysaccharides, protein, enzymes, substituents (polysaccharide-link methyl and acetyl groups), and lipids to their surrounding environment. These extracellular polymeric substances can form a hydrated biofilm matrix that acts as an external digestive system since they keep extracellular enzymes close to the cells [174].

Peng et al. [168] studied the removal of progesterone and norgestrel by the microalgae Scenedesmus obliquus and Chlorella pyrenoidosa. According to the authors, biotransformation was found to be the main mechanism for the removal of progestogens. Hydroxylation, oxidation/reduction, and side-chain breakdown were proposed to be involved in the algal transformation of the target compounds by Chlorella pyrenoidosa. Xiong et al. [169] studied the removal of carbamazepine by the microalgae Chlamydomonas mexicana and Scenedesmus obliquus. The results showed that both species simultaneously promoted biodegradation, adsorption, and bioaccumulation of carbamazepine. De Godos et al. [164] studied the mechanisms of tetracycline removal from a synthetic wastewater by Chlorella vulgaris and identified photodegradation and biosorption as the most important.

\subsubsection{Factors That Influence the Degradation Capability}

There are several factors that affect the degradation of pharmaceuticals, which are mainly related to the operation conditions, reactor configuration, and the species present. Matamoros et al. [175] studied the removal of emerging organic compounds, including pharmaceuticals, from a real wastewater by the marine algae Lessonia nigrescens Bory and Macrocystis integrifolia Bory in two pilot-scale high-rate algal ponds. Removal efficiency ranged from negligible to up to $90 \%$ and was only affected by the hydraulic retention time during the cold season. This effect was not observed in the warm season.

De Godos et al. [164] studied the removal of tetracycline by Chlorella vulgaris in two pilot-scale high-rate algal ponds operated in batch mode. The study demonstrated that the shallow geometry of high-rate algal ponds is advantageous to support tetracycline's photodegradation.

Díaz-Garduño et al. [176] studied the removal of organic compounds, including pharmaceuticals, from a real wastewater, by the microalga Coelastrum sp., in a pilot-scale photobioreactor and a multibarrier treatment. The multibarrier treatment was the most effective treatment regarding the removal efficiencies. The photobioreactor showed different removal percentages depending on the initial effluent composition. 
Hom-Diaz et al. [177] observed that the removal of pharmaceuticals from domestic wastewater in a pilot-scale tubular photobioreactor, in two seasonal periods (September-October; October-December), was highly impacted by temperature and solar irradiation.

The removal of several pharmaceuticals present in wastewater by green algal species, in a real-scale photobioreactor, was positively correlated with light intensity inside the culture, with stronger correlation when the data collected during the night were excluded [178].

Lai et al. [179] studied the removal of natural steroid estrogens (estradiol, estrone, estriol, and hydroxyestrone) and synthetic steroid estrogens (estradiol valerate, estradiol, and ethinylestradiol) by the alga Chlorella vulgaris, using batch-shaking experiments in the light and in the dark. The results showed that estradiol and estrone were interconvertible in the presence or absence of light. In the presence of light, $50 \%$ of estradiol was further metabolized to an unknown product. Estradiol valerate was hydrolyzed to estradiol and then to estrone. Estrone, hydroxyestrone, estriol and ethinylestradiol were relatively stable, and did not suffer biotransformation. Recently, a combination of photobioreactor and open-pond cultivation was suggested; the first allows a fast algae growth, while the second ensures mass cultivation [141].

In many cases, the complete removal of a compound requires the interaction of several groups of microorganisms (consortium), each of which is responsible for a degradation step. This interaction is extremely positive because pure cultures, isolated from this consortium, may not be able to completely remove this compound as the single carbon source, or the removal rate may be significantly lower than that obtained with the mixed crop that gave rise to it. Shi et al. [180] studied the removal of synthetic hormone $17 \alpha$-ethinylestradiol and the natural hormones estrone and $17 \beta$-estradiol, from a synthetic wastewater, by an alga (Anabaena cylindrica, Chlorococcus, Spirulina platensis, Chlorella, Scenedesmus quadricauda, and Anaebena) and duckweed (Lemna) pond system. The results showed that all hormones were effectively removed from the continuous-flow algae and duckweed pond even when their concentrations were at ng. $\mathrm{L}^{-1}$ level. The simultaneous presence of algae and duckweed accelerated the removal of hormones from the synthetic wastewater since hormones could be quickly sorbed either on duckweed or algae and then degraded by both microorganisms [180].

Although several studies demonstrated the applicability of algae for micropollutant removal from wastewater $[137,181]$, limitations and knowledge gaps still exist to rely on algae biomass production as an effective mean for micropollutant removal. For example, when Wang et al. [182] exposed the freshwater alga Chlorella Pyrenoidosa to a triclosan concentration of $800 \mathrm{mg} \cdot \mathrm{L}^{-1}$, a reductive dechlorination product of triclosan was formed. Algal cell growth was affected by their toxicity. Algal cell chloroplasts were damaged, decreasing the energy supply for algal growth, which produced an adverse effect on the effectiveness of triclosan biodegradation. Furthermore, most of the studies tested the algae's ability to remove pollutants, which grew in unpolluted media before the treatment, and ignored the toxic stress caused by the pollutant and its influence on the removal capability. It is possible that the sensitivity or tolerance of algae changes after the first contact with the pollutant and, therefore, it may influence the removal efficiency of subsequent batch treatments.

Chen et al. [183] investigated the removal efficiency of cefradine by Chlorella pyrenoidosa in a sequencing batch reactor and identified different results between the first batch treatment and the second, where higher algal growth inhibition rates were observed; however, the alga produced more photosynthetic pigments, enhancing its photosynthetic metabolism as a way of adaptation to more harmful environmental conditions.

\subsubsection{Concluding Remarks and Future Challenges}

Some algae strains found in the literature $[64,133,148,164,166,168-170,176-180,182-194]$ proved to be effective in pharmaceutical removal (Table 1). 
Table 1. Bioremediation studies with fungi and algae for removal of pharmaceuticals. WWTP-wastewater treatment plant.

\begin{tabular}{|c|c|c|c|c|c|}
\hline Compounds & Compounds Source & Strains & Removal Mechanisms & Technologies & Reference \\
\hline Ibuprofen, clofibric acid, and carbamazepine & Synthetic media & $\begin{array}{l}\text { Fungi } \\
\text { Trametes versicolor } \\
\text { Irpex lacteus } \\
\text { Ganoderma lucidum } \\
\text { Phanerochaete chrysosporium }\end{array}$ & $\begin{array}{l}\text { Biodegradation } \\
\text { Adsorption }\end{array}$ & Laboratory-scale batch assays & [46] \\
\hline Carbamazepine & Synthetic media & $\begin{array}{l}\text { Fungi } \\
\text { Trametes versicolor }\end{array}$ & $\begin{array}{l}\text { Biodegradation } \\
\text { Adsorption }\end{array}$ & $\begin{array}{l}\text { Laboratory-scale batch assays } \\
\text { Pilot-scale glass air-pulsed } \\
\text { fluidized bioreactor } \\
\text { (continuous and batch feed) }\end{array}$ & [47] \\
\hline $\begin{array}{l}\text { Citalopram, fluoxetine, sulfamethoxazole, diclofenac, ibuprofen, } \\
\text { naproxen, carbamazepine, and diazepam }\end{array}$ & Synthetic media & $\begin{array}{l}\text { Fungi } \\
\text { Bjerkandera sp. R1 } \\
\text { Bjerkandera adusta } \\
\text { Phanerochaete chrysosporium }\end{array}$ & Biodegradation & Laboratory-scale batch assays & [48] \\
\hline Carbamazepine & Synthetic media & $\begin{array}{l}\text { Fungi } \\
\text { Phanerochaete chrysosporium }\end{array}$ & $\begin{array}{l}\text { Biodegradation } \\
\text { Biosorption }\end{array}$ & $\begin{array}{l}\text { Pilot-scale plate bioreactor } \\
\text { (continuous and batch feed) }\end{array}$ & [49] \\
\hline $\begin{array}{l}\text { Naproxen, ibuprofen, acetaminophen, salicylic acid, ketoprofen, codeine, } \\
\text { erythromycin, metronidazole, ciprofloxacine, azithromycin, cefalexine, } \\
\text { propranolol, carbamazepine, 10,11-epoxycarbamazepine, } \\
\text { 2-hydroxycarbamazepine, acridone, and citalopram }\end{array}$ & Urban wastewater & $\begin{array}{l}\text { Fungi } \\
\text { Trametes versicolor }\end{array}$ & Biodegradation & $\begin{array}{l}\text { Pilot-scale air-fluidized } \\
\text { bioreactor (batch feed) }\end{array}$ & [50] \\
\hline $\begin{array}{l}\text { Carbamazepine, ibuprofen, clofibric acid, ketoprofen, metronidazole, } \\
\text { triclosan, } 17-\alpha \text {-ethinylestradiol, } 17-\beta \text {-estradiol-17-acetate, estrone, estriol, } \\
17-\beta \text {-estradiol, gemfibrozil, amitriptyline, primidone, salicylic acid, } \\
\text { diclofenac, naproxen }\end{array}$ & Synthetic media & $\begin{array}{l}\text { Fungi } \\
\text { Trametes versicolor }\end{array}$ & $\begin{array}{l}\text { Biodegradation } \\
\text { Biosorption }\end{array}$ & $\begin{array}{l}\text { Laboratory-scale batch assays } \\
\text { Pilot-scale fungus-augmented } \\
\text { membrane bioreactor } \\
\text { (continuous feed) }\end{array}$ & [51] \\
\hline $\begin{array}{l}\text { Acetaminophen, ibuprofen, ketoprofen, naproxen, salicylic acid, codeine, } \\
\text { phenazone, dexamethasone, diclofenac, piroxicam }\end{array}$ & Hospital wastewater & $\begin{array}{l}\text { Fungi } \\
\text { Trametes versicolor }\end{array}$ & Biodegradation & $\begin{array}{l}\text { Pilot-scale glass air pulsed } \\
\text { fluidized bioreactor (batch feed) }\end{array}$ & [52] \\
\hline X-ray contrast agent iopromide and antibiotic ofloxacin & Hospital wastewater & $\begin{array}{l}\text { Fungi } \\
\text { Trametes versicolor }\end{array}$ & Biodegradation & $\begin{array}{l}\text { Laboratory-scale batch assays } \\
\text { Pilot-scale glass air-pulsed } \\
\text { fluidized bioreactor (batch feed) }\end{array}$ & [53] \\
\hline $\begin{array}{l}\text { Metronidazole, salicylic acid, primidone, amitriptyline, carbamazepine, } \\
\text { ketoprofen, naproxen, ibuprofen, gemfibrozil, diclofenac, triclosan, } \\
\text { estriol, estrone, } 17-\alpha \text {-ethinylestradiol, } 17-\beta \text {-estradiol, } \\
\text { 17- } \beta \text {-estradiol-17-acetate }\end{array}$ & Synthetic media & $\begin{array}{l}\text { Fungi } \\
\text { Trametes versicolor }\end{array}$ & $\begin{array}{l}\text { Biodegradation } \\
\text { Biosorption }\end{array}$ & Laboratory-scale batch assays & [54] \\
\hline $\begin{array}{l}\text { Cefalexin, ciprofloxacin, metronidazole, trimethoprim, tetracycline, } \\
\text { ketoprofen, acridone, carbamazepine, a carbamazepine metabolite, } \\
\text { ciprofloxacin, metronidazole and its hydroxilated metabolite, } \beta \text {-blocker } \\
\text { carazolol, diazepam, naproxen, cephalexin, tetracyclin, sertraline, } \\
\text { paroxetine, gemfibrozil, amlodipine, furosemide, dimetridazole, } \\
\text { azythromycin, ronidazole, olanzapine, piroxicam, } \beta \text {-blockers metoprolol }\end{array}$ & $\begin{array}{l}\text { Veterinary hospital } \\
\text { wastewater }\end{array}$ & $\begin{array}{l}\text { Fungi } \\
\text { Trametes versicolor }\end{array}$ & Biodegradation & $\begin{array}{l}\text { Pilot-scale glass air-pulsed } \\
\text { fluidized bioreactor } \\
\text { (continuous and batch feed) }\end{array}$ & [55] \\
\hline
\end{tabular}


Table 1. Cont.

\begin{tabular}{|c|c|c|c|c|c|}
\hline Compounds & Compounds Source & Strains & Removal Mechanisms & Technologies & Reference \\
\hline $\begin{array}{l}\text { Acetaminophen, carbamazepine, diclofenac, metoprolol, naproxean, } \\
\text { ranitidine, and sulfamethoxazole }\end{array}$ & Synthetic media & $\begin{array}{l}\text { Fungi } \\
\text { Aspergillus niger } \\
\text { Algae } \\
\text { Chlorella vulgaris }\end{array}$ & Biodegradation & Laboratory-scale batch assays & [56] \\
\hline Estrone, $17 \beta$-estradiol, $17 \alpha$-ethinyl-estradiol, and estriol & WWTP wastewater & $\begin{array}{l}\text { Fungi } \\
\text { Trametes versicolor } \\
\text { Myceliophthora thermophila }\end{array}$ & $\begin{array}{l}\text { Biodegradation } \\
\text { Adsorption }\end{array}$ & Laboratory-scale batch assays & [57] \\
\hline $17 \beta$-estradiol and $17 \alpha$-ethinylestradiol & Synthetic media & $\begin{array}{l}\text { Fungi } \\
\text { Trametes versicolor }\end{array}$ & Biodegradation & $\begin{array}{l}\text { Laboratory-scale batch assays } \\
\text { Pilot-scale glass air-fluidized } \\
\text { bioreactor (continuous feed) }\end{array}$ & [58] \\
\hline Sulfapyridine, sulfapyridine, and sulfamethazine & Synthetic media & $\begin{array}{l}\text { Fungi } \\
\text { Trametes versicolor }\end{array}$ & $\begin{array}{l}\text { Biodegradation } \\
\text { Biosorption }\end{array}$ & $\begin{array}{l}\text { Laboratory-scale batch assays } \\
\text { Pilot-scale air-pulsed } \\
\text { fluidized-bed bioreactor } \\
\text { (continuous feed) }\end{array}$ & [59] \\
\hline Naproxen and carbamazepine & Synthetic media & $\begin{array}{l}\text { Fungi } \\
\text { Trametes versicolor }\end{array}$ & Biodegradation & Laboratory-scale batch assays & [60] \\
\hline Sodium diclofenac & Synthetic media & $\begin{array}{l}\text { Fungi } \\
\text { Trametes versicolor }\end{array}$ & Biodegradation & Laboratory-scale batch assays & [61] \\
\hline Ketoprofen & Synthetic media & $\begin{array}{l}\text { Fungi } \\
\text { Trametes versicolor }\end{array}$ & Biodegradation & Laboratory-scale batch assays & [62] \\
\hline Diclofenac, ibuprofen, naproxen, carbamazepine, and diazepam & Synthetic media & $\begin{array}{l}\text { Fungi } \\
\text { Phanerochaete chrysosporium }\end{array}$ & $\begin{array}{l}\text { Biodegradation } \\
\text { Adsorption }\end{array}$ & $\begin{array}{l}\text { Pilot-scale stirred tank reactor } \\
\text { and fixed-bed reactor } \\
\text { (continuous feed) }\end{array}$ & {$[64]$} \\
\hline Tetracycline and oxytetracycline & Synthetic media & $\begin{array}{l}\text { Fungi } \\
\text { Phanerochaete chrysosporium }\end{array}$ & Biodegradation & Laboratory-scale batch assays & {$[65]$} \\
\hline Phenolic compounds & $\begin{array}{l}\text { Pharmaceutical } \\
\text { industry wastewater }\end{array}$ & Pycnoporus sanguineus & Biodegradation & Laboratory-scale batch assays & [66] \\
\hline Diclofenac, ketoprofen and atenolol & Hospital wastewater & $\begin{array}{l}\text { Fungi } \\
\text { Pleurotus ostreatus }\end{array}$ & $\begin{array}{l}\text { Biodegradation } \\
\text { Adsorption }\end{array}$ & $\begin{array}{l}\text { Pilot-scale air-pulsed } \\
\text { fluidized-bed bioreactor } \\
\text { (continuous and batch feed) } \\
\text { Laboratory-scale batch assays }\end{array}$ & [67] \\
\hline
\end{tabular}


Table 1. Cont.

\begin{tabular}{|c|c|c|c|c|c|}
\hline Compounds & Compounds Source & Strains & Removal Mechanisms & Technologies & Reference \\
\hline $17 \alpha$-ethinylestradiol and carbamazepine & Synthetic media & $\begin{array}{l}\text { Fungi } \\
\text { Pleurotus sp. P1 } \\
\text { Pleurotus ostreatus BS } \\
\text { (unidentified) } \\
\text { basidiomycete strain BNI }\end{array}$ & $\begin{array}{l}\text { Biodegradation } \\
\text { Adsorption }\end{array}$ & Laboratory-scale batch assays & [68] \\
\hline Acetaminophen & Synthetic media & $\begin{array}{l}\text { Fungi } \\
\text { Mucor hiemalis }\end{array}$ & Bioconcentration & Laboratory-scale batch assays & [69] \\
\hline Carbamazepine and clarithromycin & Synthetic media & $\begin{array}{l}\text { Fungi } \\
\text { Trichoderma } \\
\text { harzianumPleurotus ostreatus }\end{array}$ & Biodegradation & Laboratory-scale batch assays & [70] \\
\hline Carbamazepine & Synthetic media & $\begin{array}{l}\text { Fungi } \\
\text { Pleurotus ostreatus }\end{array}$ & Biodegradation & Laboratory-scale batch assays & [71] \\
\hline $\begin{array}{l}\text { Clofibric acid, gemfibrozil, ibuprofen, fenoprofen, ketoprofen, naproxen, } \\
\text { diclofenac, indomethacin, propyphenazone, and carbamazepine }\end{array}$ & Synthetic media & $\begin{array}{l}\text { Fungi } \\
\text { Trametes versicolor }\end{array}$ & Biodegradation & Laboratory-scale batch assays & [72] \\
\hline Levofloxacin & Synthetic media & $\begin{array}{l}\text { Algae } \\
\text { Chlorella vulgaris }\end{array}$ & $\begin{array}{l}\text { Biodegradation } \\
\text { Bioaccumulation }\end{array}$ & Laboratory-scale batch assays & [133] \\
\hline $\begin{array}{l}\text { Acetaminophen, ibuprofen, ketoprofen, naproxen, carbamazepine, } \\
\text { diclofenac, and triclosan }\end{array}$ & WWTP wastewater & $\begin{array}{l}\text { Algae } \\
\text { Lessonia nigrescens Bory } \\
\text { Macrocystis integrifolia Bory }\end{array}$ & $\begin{array}{l}\text { Biodegradation } \\
\text { Photodegradation } \\
\text { Biosorption }\end{array}$ & Pilot-scale high-rate algal ponds & [148] \\
\hline Tetracycline & Synthetic media & $\begin{array}{l}\text { Algae } \\
\text { Chlorella vulgaris }\end{array}$ & $\begin{array}{l}\text { Photodegradation } \\
\text { Biosorption }\end{array}$ & $\begin{array}{l}\text { Laboratory-scale batch assays } \\
\text { Pilot-scale high rate algal ponds } \\
\text { (batch feed) }\end{array}$ & [164] \\
\hline Carbamazepine & Synthetic media & $\begin{array}{l}\text { Algae } \\
\text { Pseudokirchneriella } \\
\text { subcapitata } \\
\text { (and crustacean } \\
\text { Thamnocephalus and } \\
\text { cnidarian Hydra attenuata) }\end{array}$ & Bioaccumulation & Laboratory-scale batch assays & [166] \\
\hline Progesterone and norgestrel & Synthetic media & $\begin{array}{l}\text { Algae } \\
\text { Scenedesmus obliquus } \\
\text { Chlorella pyrenoidosa }\end{array}$ & $\begin{array}{l}\text { Biodegradation } \\
\text { Biosorption }\end{array}$ & Laboratory-scale batch assays & [168] \\
\hline Carbamazepine & Synthetic media & $\begin{array}{l}\text { Algae } \\
\text { Chlamydomonas mexicana } \\
\text { Scenedesmus obliquus }\end{array}$ & $\begin{array}{l}\text { Biodegradation } \\
\text { Adsorption } \\
\text { Bioaccumulation }\end{array}$ & Laboratory-scale batch assays & [169] \\
\hline
\end{tabular}


Table 1. Cont.

\begin{tabular}{|c|c|c|c|c|c|}
\hline Compounds & Compounds Source & Strains & Removal Mechanisms & Technologies & Reference \\
\hline $17 \alpha$-Ethynylestradiol & Synthetic media & $\begin{array}{l}\text { Algae } \\
\text { Desmodesmus subspicatus }\end{array}$ & $\begin{array}{l}\text { Biotransformation } \\
\text { Bioconcentration }\end{array}$ & Laboratory-scale batch assays & {$[170]$} \\
\hline $\begin{array}{l}\text { Analgesic and antiinflammatories, lipid regulators and antihypertensive, } \\
\text { psychiatric drugs and stimulant, antibiotics, and others }\end{array}$ & WWTP wastewater & $\begin{array}{l}\text { Algae } \\
\text { Coelastrum sp. }\end{array}$ & Biodegradation & $\begin{array}{l}\text { Pilot-scale photobiotreatment } \\
\text { microalgae and multi-barrier } \\
\text { treatment }\end{array}$ & [176] \\
\hline $\begin{array}{l}\text { Acetaminophen, ibuprofen, naproxen, salicylic acid, ketoprofen, codeine, } \\
\text { azithromycin, erythromycin, ciprofloxacin, ofloxacin, atenolol, } \\
\text { lorazepam, alprazolam, paroxetine, hydrochlorothiazide, furosemide, } \\
\text { and diltiazem }\end{array}$ & $\begin{array}{l}\text { Domestic } \\
\text { wastewater }\end{array}$ & $\begin{array}{l}\text { Algae } \\
\text { Undefined microalgae }\end{array}$ & Biodegradation & $\begin{array}{l}\text { Pilot-scale tubular } \\
\text { photobioreactor }\end{array}$ & [177] \\
\hline $\begin{array}{l}\text { Alfuzosin, alprazolam, atenolol, atracurium, azelastine, biperiden, } \\
\text { bisoprolol, bupropion, carbamazepin, cilazapril, ciprofloxacin, } \\
\text { citalopram, clarithromycine, clemastine, clindamycine, clonazepam, } \\
\text { clotrimazol, codeine, cyproheptadine, desloratidin, dicycloverin, } \\
\text { diltiazem, diphenhydramin, eprosartan, fexofenadine, flecainide, } \\
\text { fluconazole, flupetixol, haloperidol, hydroxyzine, ibersartan, loperamide, } \\
\text { memantin, metoprolol, miconazole, mirtazapine, nefazodon, } \\
\text { orphenadrin, pizotifen, ranitidine, risperidone, roxithromycine, } \\
\text { sertraline, sotalol, sulfamethoxazol, terbutalin, tramadol, } \\
\text { trihexyphenidyl, trimetoprim, venlavafaxin, and verapamil }\end{array}$ & WWTP wastewater & $\begin{array}{l}\text { Algae } \\
\text { Green algal species } \\
\text { (Tetradesmus dimorphus and } \\
\text { Dictyosphaerium, between } \\
\text { them) }\end{array}$ & Biodegradation & Real-scale photobioreactor & [178] \\
\hline $\begin{array}{l}\text { Estradiol, estrone, estriol and hydroxyestrone) and synthetic steroid } \\
\text { estrogens (estradiol valerate, estradiol, and ethinylestradiol }\end{array}$ & Synthetic media & $\begin{array}{l}\text { Algae } \\
\text { Chlorella vulgaris }\end{array}$ & $\begin{array}{l}\text { Biotransformation } \\
\text { Bioconcentration }\end{array}$ & Laboratory-scale batch assays & [179] \\
\hline $17 \alpha$-ethinylestradiol, estrone, and $17 \beta$-estradiol & Synthetic media & $\begin{array}{l}\text { Algae } \\
\text { Anabaena cylindrical } \\
\text { Chlorococcus } \\
\text { Spirulina platensis } \\
\text { Chlorella } \\
\text { Scenedesmus quadricauda } \\
\text { Anaebena } \\
\text { (and duckweed Lemna) }\end{array}$ & $\begin{array}{l}\text { Biodegradation } \\
\text { Adsorption }\end{array}$ & $\begin{array}{l}\text { Laboratory-scale batch assays } \\
\text { Pilot-scale plug flow reactor } \\
\text { (continuous feed) }\end{array}$ & [180] \\
\hline Triclosan & Synthetic media & $\begin{array}{l}\text { Algae } \\
\text { Chlorella Pyrenoidosa }\end{array}$ & $\begin{array}{l}\text { Biodegradation } \\
\text { Biosorption }\end{array}$ & Laboratory-scale batch assays & [182] \\
\hline Cefradinegree & Synthetic media & $\begin{array}{l}\text { Algae } \\
\text { Chlorella pyrenoidosa }\end{array}$ & Biodegradation & $\begin{array}{l}\text { Pilot-scale batch-sequencing } \\
\text { reactor algae process (batch } \\
\text { feed) }\end{array}$ & [183] \\
\hline
\end{tabular}


Table 1. Cont

\begin{tabular}{|c|c|c|c|c|c|}
\hline Compounds & Compounds Source & Strains & Removal Mechanisms & Technologies & Reference \\
\hline Ethinylestradiol & Synthetic media & $\begin{array}{l}\text { Algae } \\
\text { Ankistrodesmus braunii } \\
\text { Chlorella ellipsoidea } \\
\text { Chlorella pyrenoidosa } \\
\text { Chlorella vulgaris } \\
\text { Scenedesmus communis } \\
\text { Scenedesmus obliquus } \\
\text { Scenedesmus quadricauda } \\
\text { Scenedesmus vacuolatus } \\
\text { Selenastrum capricornutum }\end{array}$ & Biotransformation & Laboratory-scale batch assays & [184] \\
\hline $\begin{array}{l}17 \alpha \text {-boldenone, } 17 \beta \text {-boldenone, 4-hydroxy-androst-4-ene-17-dione, } \\
\text { androsta-1,4-diene-3,17-dione, } 4 \text {-androstene-3,17-dione, carbamazepine, } \\
\text { ciprofloxacin, clarithromycin, climbazole, clofibric acid, diclofenac, } \\
\text { enrofloxacin, erythromycin- } \mathrm{H}_{2} \mathrm{O} \text {, estrone, fluconazole, gemfibrozil, } \\
\text { ibuprofen, lincomycin, lomefloxacin, norfloxacin, ofloxacin, paracetamol, } \\
\text { progesterone, roxithromycin, salicylic acid, salinomycin, sulfadiazine, } \\
\text { sulfadimethoxine, sulfameter, sulfamethazine, sulfamethoxzole, } \\
\text { sulfamonomethoxine, sulfapyridine, testosterone, triclosan, } \\
\text { trimethoprim, and tylosin }\end{array}$ & WWTP wastewater & $\begin{array}{l}\text { Algae } \\
\text { Chlamydomonas reinhardtii } \\
\text { Scenedesmus obliquus } \\
\text { Chlorella pyrenoidosa } \\
\text { Chlorella vulgaris }\end{array}$ & Biodegradation & Laboratory-scale batch assays & [185] \\
\hline Salicylic acid and paracetamol & Synthetic media & $\begin{array}{l}\text { Algae } \\
\text { Chlorella sorokiniana }\end{array}$ & Biodegradation & $\begin{array}{l}\text { Pilot-scale reactor (batch and } \\
\text { semicontinuous feed) }\end{array}$ & [186] \\
\hline Paracetamol, salicylic acid, and diclofenac & Synthetic media & $\begin{array}{l}\text { Algae } \\
\text { Chlorella sorokiniana } \\
\text { Chlorella vulgaris } \\
\text { Scenedesmus obliquus }\end{array}$ & Biodegradation & $\begin{array}{l}\text { Pilot-scale bubbling column } \\
\text { photobioreactor (batch and } \\
\text { semicontinuous feed) }\end{array}$ & [187] \\
\hline Tributyltin & Synthetic media & $\begin{array}{l}\text { Algae } \\
\text { Chlorella miniata } \\
\text { C. sorokiniana } \\
\text { Scenedesmus dimorphus } \\
\text { S. platydiscus }\end{array}$ & $\begin{array}{l}\text { Biodegradation } \\
\text { Adsorption } \\
\text { Absorption }\end{array}$ & Laboratory-scale batch assays & [188] \\
\hline Trimethoprim, sulfamethoxazole, and triclosan & Synthetic media & $\begin{array}{l}\text { Algae } \\
\text { Nannochloris Sp. }\end{array}$ & $\begin{array}{l}\text { Biodegradation } \\
\text { Adsorption }\end{array}$ & Laboratory-scale batch assays & [189] \\
\hline $\begin{array}{l}\text { Diclofenac, ibuprofen, paracetamol, metoprolol, carbamazepine and } \\
\text { trimethoprim, estrone, } 17 \beta \text {-estradiol, and ethinylestradiol }\end{array}$ & Synthetic media & $\begin{array}{l}\text { Algae } \\
\text { Chlorella sorokiniana }\end{array}$ & $\begin{array}{l}\text { Biodegradation } \\
\text { Photolysis } \\
\text { Biosorption }\end{array}$ & Laboratory-scale batch assays & [190] \\
\hline
\end{tabular}


Table 1. Cont.

\begin{tabular}{|c|c|c|c|c|c|}
\hline Compounds & Compounds Source & Strains & Removal Mechanisms & Technologies & Reference \\
\hline Oxytetracycline, doxycycline, chlortetracycline, and tetracycline & Synthetic media & $\begin{array}{l}\text { Algae } \\
\text { Haematoloccus pluvialis } \\
\text { Chlorella sp. } \\
\text { Selenastrum capricornutum } \\
\text { Pseudokirchneriella } \\
\text { subcapitata }\end{array}$ & Biodegradation & Laboratory-scale batch assays & [191] \\
\hline Salicylic acid or paracetamol & $\begin{array}{l}\text { Pharmaceutical } \\
\text { industry wastewater }\end{array}$ & $\begin{array}{l}\text { Algae } \\
\text { Chlorella sorokiniana }\end{array}$ & Biodegradation & $\begin{array}{l}\text { Pilot-scale bubbling column } \\
\text { photobioreactor (batch and } \\
\text { semicontinuous feed) }\end{array}$ & [193] \\
\hline Ciprofloxacin & Synthetic media & $\begin{array}{l}\text { Algae } \\
\text { Chlamydomonas mexicana }\end{array}$ & Biodegradation & Laboratory-scale batch assays & [194] \\
\hline$\beta$-estradiol and $17 \alpha$-ethinylestradiol & $\begin{array}{l}\text { WWTP anaerobic } \\
\text { sludge }\end{array}$ & $\begin{array}{l}\text { Algae } \\
\text { Selenastrum capricornutum } \\
\text { Chlamydomonas reinhardtii }\end{array}$ & $\begin{array}{l}\text { Biodegradation } \\
\text { Photodegradation } \\
\text { Adsorption }\end{array}$ & Laboratory-scale batch assays & [195] \\
\hline
\end{tabular}


Chen et al. [182] raised a question worthy for future researches related to the possible improvement of the removal efficiency of pollutants by algae under optimal light conditions and after their acclimation.

The final step of the treatment, harvesting, which represents a significant amount of the production cost and energy consumption, is one of the most challenging processes. One of the most environmentally friendly methods is bioflocculation [150,151]; nevertheless, it may not be efficient enough due to the small size of microalgae cells. Other technologies, namely, co-pelletization through the addition of other microorganisms (bacterial and fungal species) to microalgae culture, which do not require the addition of chemicals or inputs of energy, may be promising solutions. However, further research on this topic is recommended.

Such as for mycoremediation, genetic tools can represent an essential step to improve algae performance. However, genetically modified algae for bioremediation are rarely reported. An example is a small laccase from Streptomyces coelicolor that was engineered by structure-based design and site-directed mutagenesis to improve its activity on commercially relevant substrates. The variants generated showed up to a 40-fold increased efficiency on 2,6-dimethoxyphenol, as well as the ability to use mediators with considerably higher redox potentials [195].

\section{Biosorption}

Adsorption includes all the processes involving a physical or chemical interaction between the surface of a solid material (adsorbent) and the pollutant (adsorbate); biosorption is a subcategory of adsorption, and may be simply defined as the removal of substances from solution by biological material (live or dead). It is a property of living and dead biomass to bind and abiotically concentrate compounds [196,197]. In addition to being an efficient and low-cost process, biosorption offers advantages over conventional processes, and avoids the use of chemicals, namely, nutrient supply [197].

\subsection{Biosorption Materials}

Activated carbon is the most widely and effectively used sorbent, since it has a porous structure consisting of a network of interconnected macropores, mesopores, and micropores that provide a good capacity for the adsorption of organic molecules due to its high specific surface area. However, it is quite expensive, United States (US) \$20-22/kg [198], and the higher the quality is, the greater the cost is $[199,200]$, which limits its widespread use. According to the Swedish Environmental Protection Agency [201], the costs depend mainly on the size of the treatment plant. For facilities using granular activated carbon, for 2000-10,000 population equivalent, the following costs are associated: 0.72 million US \$ for installation, 0.04 million US \$/year of capital expenditure, 0.1 million US \$/year of operating expenditure, and less than $0.01 \mathrm{kWh} / \mathrm{m}^{3}$ of operational electricity consumption, corresponding to a total cost of $0.09-0.11$ US $\$ / \mathrm{m}^{3}$ of treated wastewater. It is verified that the annual operating expenditure has a major contribution to the total cost and that the major fraction of the operating costs is due to activated carbon, which demonstrates the need to look for low-cost adsorbents. This led to the search for low-cost sorbents, which require little processing and that are abundant in nature [202]. In this search, biosorbents from microorganisms were shown to be a promising alternative since, due to their reduced size, they present high specific surface area and they were shown to be able to sorb different organic and inorganic pollutants from solutions [203]. A wide range of microorganisms were studied in biosorption processes; these include microalgae and fungi. The complexity of the microorganism structure implies that there are many ways for the contaminants to be captured by the cells; in some cases, these are still not very well understood. The cell wall is the first component that meets the pollutants, where the solutes can be deposited on the surface or within the cell-wall structure.

Fungal cell walls are structurally complex with several functional groups such as carboxyl, hydroxyl, amino, sulfonate, and phosphonate, which bring about the excellent adsorption properties of fungi [204-208].

Algal cell walls exhibit some variations in their structure. The main groups present are amino, amine, hydroxyl, imidazole, phosphate, and sulfate [209]. This availability of functional groups 
minimizes the selectivity problems and allows the high efficiency of removal to be more easily achieved [210]. For example, Navarro et al. [211] proposed the formation of hydrogen bonds as the main mechanism for the removal of sulfamethoxazole and sulfacetamide by marine algae Lessonia nigrescens Bory and Macrocystis integrifolia Bory.

\subsection{Treatment Systems}

Biosorption can proceed in batch or continuous mode. Both modes are frequently employed to conduct laboratory-scale experiments, while continuous mode is the most employed for industrial applications. Packed-bed, fluidized-bed, and continuous-stirred-bed reactors are three types of design used in biosorption experiments. Several studies showed that packed-bed columns are the most suitable for liquid-solid separation, and scaling was found to be minimal [212,213]. Fluidized-bed and continuous-stirred-bed reactors are only occasionally used, since fluidized-bed reactors require a high flow rate, which is sometimes difficult to achieve, and stirred-bed reactors require that biomass be in powdered form; beyond that, they have high associated costs and high requirements of operation and maintenance $[207,214]$.

In the last few decades, many patents were developed, focused on improving the sorption capacity of biosorbents through their modification or immobilization, mainly for metal removal [197]. However, further attention should be given to the removal of pharmaceuticals.

\subsection{Mechanisms of Removal}

Biosorption is a physico-chemical process that involves several mechanisms (e.g., adsorption, ion exchange, surface complexation, and microprecipitation), as shown in Figure 4 [215]. Biosorbent surfaces are characterized by active, energy-rich sites that are able to interact with compounds in the adjacent aqueous phase due to their specific electronic and spatial properties. Sorption occurs because, from the thermodynamic point of view, the molecules prefer to be in a low-energy state. A molecule sorbed onto a surface has a lower energetic state on a surface than in the aqueous phase. Therefore, the molecule is attracted to the surface and to a lower-energy state. The attraction of a molecule to a surface can be caused by physical and/or chemical forces. Electrostatic forces govern the interactions between most sorbates and biosorbents. These forces include dipole-dipole interactions or London/van der Waals forces, and hydrogen bonds [216].

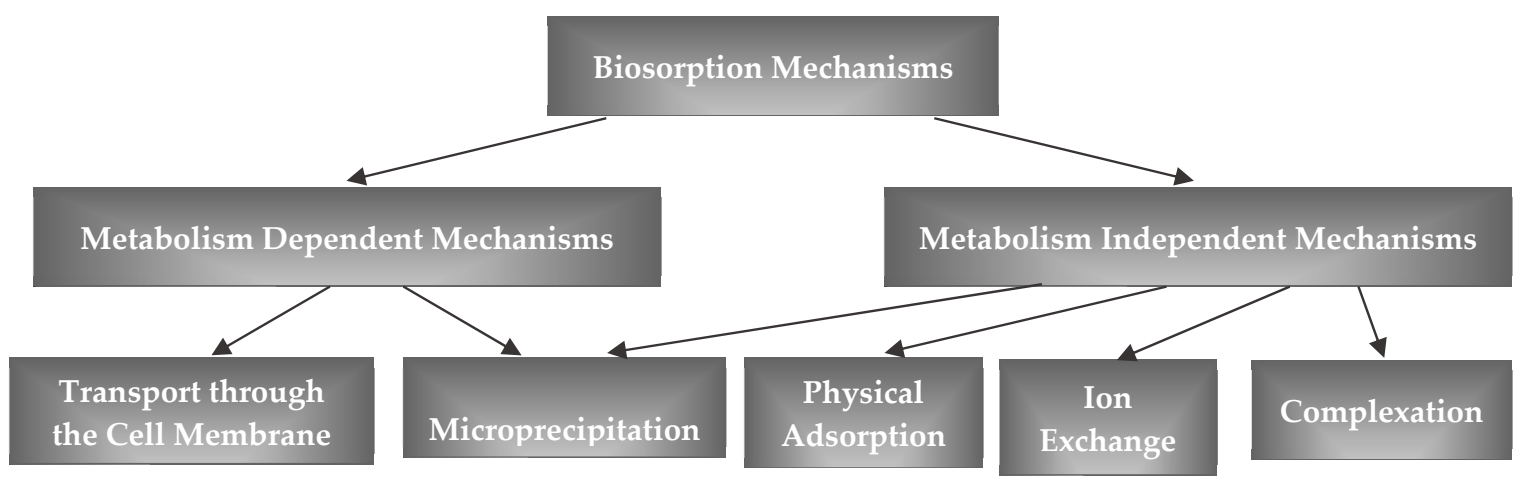

Figure 4. Biosorption mechanisms.

Biosorption equilibrium is not established instantaneously. The mass transfer from the solution to the sorption sites within the adsorbent particles is constrained by mass transfer resistances that determine the time required to reach the state of equilibrium. The rate of adsorption is usually limited by diffusion processes toward the external adsorbent surface and within the porous adsorbent particles.

The progress of the biosorption process includes four consecutive steps: transport of the sorbate from the bulk liquid phase to the hydrodynamic boundary layer localized around the biosorbent particle; transport through the boundary layer to the external surface of the biosorbent, termed film 
diffusion or external diffusion; pore diffusion and/or surface diffusion toward the interior of the biosorbent particle (termed intraparticle diffusion or internal diffusion); and energetic interaction between the sorbate molecules and the sorption sites.

Kinetic and equilibrium data are modeled using different approaches in order to explain the biosorption mechanism of the pollutants' removal [217]. The equilibrium distribution on the sorbed pollutant between the biosorbent and the aqueous phase is required to determine the maximum biosorbent's uptake capacity. The sorption kinetics provides additional important information about the sorption mechanism, especially the rate of pollutant removal. In wastewater treatment, kinetics information is important for setting an optimum residence time of the wastewater at the biosolid phase interface.

Typically, the dependence of the sorbed amount on the equilibrium concentration is determined experimentally at constant temperature, and the measured data are subsequently described by an appropriate isotherm equation.

For fixed-bed columns, the dynamic behavior and efficiency are described in terms of the effluent/affluent concentration as a function of time (or volume of treated liquid), i.e., the breakthrough curve. Experimental "breakthrough curve" determination allows verifying the applicability of a chosen adsorption model for a given biosorbent/sorbate system and estimating the related mass transfer coefficients [217].

\subsection{Factors That Affect the Process}

Several factors affect biosorption; most of them are common to adsorption processes, like $\mathrm{pH}$, temperature, contaminant concentration, nature of sorbent and sorbate, contact time, ionic strength, the presence of other compounds, the use of dead or alive biomass [196,214,218], and the presence/absence of metabolic processes, in the case of living cells [215]. In living organisms, metabolic processes may affect physico-chemical biosorption mechanisms, pollutant bioavailability, chemical speciation, and accumulation/transformation [196].

Organic pollutants have a wide diversity of chemical structures; therefore, factors such as the molecular size, charge, solubility, hydrophobicity, and reactivity are important factors in biosorption. Human pharmaceutical metabolites, for example, are usually more polar and hydrophilic than the parent compounds; therefore, it is expected that they will not be significantly removed by sorption [219].

By changing the properties of the liquid phase (e.g., concentration, temperature, $\mathrm{pH}$ ), sorbed species may be released from the surface and transferred back into the liquid phase. This reverse process is referred to as desorption.

In the study of Aksu and Tunc [220], the removal of penicillin G potassium salt by dried fungus Rhizopus arrhizus was strongly dependent on the $\mathrm{pH}$ and temperature. Maximum sorption was observed at initial $\mathrm{pH}$ values of 6.0 and at $35{ }^{\circ} \mathrm{C}$. They also [220] explored the possibility of using the dried fungus for the batch removal of penicillin $G$ potassium salt from aqueous solution and compared the experimental uptake with the results obtained with powdered activated carbon, in the same conditions. The uptake capacity determined was $459.0 \mathrm{mg} \cdot \mathrm{g}^{-1}$ and $375.0 \mathrm{mg} \cdot \mathrm{g}^{-1}$ for dried Rhizopus arrhizus and for an activated carbon (commercial powdered activated carbon, SIGMA, C-4386, washed with hydrochloric acid), respectively.

The use of dead biomass has advantages compared to the use of live biomass, such as the absence of toxicity limitations and the absence of nutrient requirement for microorganism's growth; however, live biomass has the advantage of using metabolic processes that complement the overall removal process [220].

Tam et al. [188] investigated tributyltin removal from artificial wastewater by dead and live cells of four microalgal species, Chlorella miniata, Chlorella sorokiniana, Scenedesmus dimorphus, and Scenedesmus platydiscus. In general, dead cells were more efficient than live cells during the three days of exposure; however, at the end of 14 days, removal efficiencies were identical to those that were reached by live cells. More than $90 \%$ and $85 \%$ of tributyltin was removed by dead cells of Scenedesmus 
and Chlorella, respectively, in the first three days. After three days of treatment, total amount of sorbed tributyltin per unit of biomass for dead cells of Chlorella miniata, Chlorella sorokiniana, Scenedesmus dimorphus, and Scenedesmus platydiscus was, respectively, $11.3 \pm 0.6,4.0 \pm 0.3,1.31 \pm 0.09$, and $0.35 \pm 0.04 \mathrm{mg} \cdot \mathrm{g}^{-1}$, while, for live cells, it was, respectively, $0.24 \pm 0.03,0.58 \pm 0.12,0.083 \pm 0.003$, and $0.0603 \pm 0.0005 \mathrm{mg} \cdot \mathrm{g}^{-1}$. Many other studies allowed observing that the fast concentration decrease in the beginning of the assays was caused by the sorption process, followed by a much slower concentration decrease caused by other biological removal mechanisms. This fact is probably due to the large surface area of the individual cells, which provides a large interface between the aqueous and cell phases. Nevertheless, unlike the other removal mechanisms, sorption is an equilibrium process that ends when equilibrium is reached, which may lead to an incomplete removal of pollutants $[164,180,182,189]$. Combining biosorption with other removal mechanisms seems to be a successful strategy for the removal of pharmaceuticals.

\subsection{Biosorption Potential as a Wastewater Treatment Technology}

The potential of biosorption as a wastewater treatment technology was frequently cited in the literature, as shown in Table 2. Usually, the performance of commercial adsorbents is very good due to the high specific surface area and the high porosity, but they present high costs which prevents their wide use, especially when high flowrates are involved. The use of biosorbents, which are usually easily available, presents advantages such as their low cost, and a more eco-friendly and sustainable nature. Like bioremediation, several aspects make biosorption a promising choice, since it is a low-cost treatment, has low operating costs, does not produce chemical sludge to handle, and is highly efficient [221]. Some disadvantages associated with the process are the low specificity and low robustness of the systems [222], the impossibility of long-term use of the suspended biomass, and the difficult separation of the biomass and the treated effluent [223]. The use of packed-bed columns is considered the most suitable biosorption, allowing an easy liquid-solid separation. The use of biosorbents in granulated form instead of powdered form presents the advantage of avoiding column clogging. Furthermore, the immobilization of fungi and algae can increase the efficiency of the process as it allows their use for several cycles [224]. 
Table 2. Biosorption studies with fungi and algae for removal of pharmaceuticals.

\begin{tabular}{|c|c|c|c|c|c|}
\hline Compounds & Compounds Source & Strains & Removal Mechanisms & Technologies & Reference \\
\hline Ibuprofen, clofibric acid, and carbamazepine & Synthetic media & $\begin{array}{l}\text { Fungi } \\
\text { Trametes versicolor } \\
\text { Irpex lacteus } \\
\text { Ganoderma lucidum } \\
\text { Phanerochaete chrysosporium }\end{array}$ & $\begin{array}{l}\text { Biodegradation } \\
\text { Adsorption }\end{array}$ & Laboratory-scale batch assays & [46] \\
\hline Carbamazepine & Synthetic media & $\begin{array}{l}\text { Fungi } \\
\text { Trametes versicolor }\end{array}$ & $\begin{array}{l}\text { Biodegradation } \\
\text { Adsorption }\end{array}$ & $\begin{array}{l}\text { Laboratory-scale batch assays } \\
\text { Pilot-scale glass air-pulsed } \\
\text { fluidized bioreactor } \\
\text { (continuous and batch feed) }\end{array}$ & [47] \\
\hline Carbamazepine & Synthetic media & $\begin{array}{l}\text { Fungi } \\
\text { Phanerochaete chrysosporium }\end{array}$ & $\begin{array}{l}\text { Biodegradation } \\
\text { Biosorption }\end{array}$ & $\begin{array}{l}\text { Pilot-scale plate bioreactor } \\
\text { (continuous and batch feed) }\end{array}$ & [49] \\
\hline $\begin{array}{l}\text { Carbamazepine, ibuprofen, clofibric acid, ketoprofen, metronidazole, } \\
\text { triclosan, } 17-\alpha \text {-ethinylestradiol, } 17-\beta \text {-estradiol-17-acetate, estrone, } \\
\text { estriol, } 17-\beta \text {-estradiol, gemfibrozil, amitriptyline, primidone, salicylic } \\
\text { acid, diclofenac, naproxen }\end{array}$ & Synthetic media & $\begin{array}{l}\text { Fungi } \\
\text { Trametes versicolor }\end{array}$ & $\begin{array}{l}\text { Biodegradation } \\
\text { Biosorption }\end{array}$ & $\begin{array}{l}\text { Laboratory-scale batch assays } \\
\text { Pilot-scale fungus-augmented } \\
\text { membrane bioreactor } \\
\text { (continuous feed) }\end{array}$ & [51] \\
\hline $\begin{array}{l}\text { Metronidazole, salicylic acid, primidone, amitriptyline, } \\
\text { carbamazepine, ketoprofen, naproxen, ibuprofen, gemfibrozil, } \\
\text { diclofenac, triclosan, estriol, estrone, } 17-\alpha \text {-ethinylestradiol, } \\
\text { 17- } \beta \text {-estradiol, } 17-\beta \text {-estradiol-17-acetate }\end{array}$ & Synthetic media & $\begin{array}{l}\text { Fungi } \\
\text { Trametes versicolor }\end{array}$ & $\begin{array}{l}\text { Biodegradation } \\
\text { Biosorption }\end{array}$ & Laboratory-scale batch assays & [54] \\
\hline Estrone, $17 \beta$-estradiol, $17 \alpha$-ethinylestradiol, and estriol & WWTP wastewater & $\begin{array}{l}\text { Fungi } \\
\text { Trametes versicolor } \\
\text { Myceliophthora thermophila }\end{array}$ & $\begin{array}{l}\text { Biodegradation } \\
\text { Adsorption }\end{array}$ & Laboratory-scale batch assays & [57] \\
\hline Sulfapyridine, sulfapyridine, and sulfamethazine & Synthetic media & $\begin{array}{l}\text { Fungi } \\
\text { Trametes versicolor }\end{array}$ & $\begin{array}{l}\text { Biodegradation and } \\
\text { biosorption }\end{array}$ & $\begin{array}{l}\text { Laboratory-scale batch assays } \\
\text { Pilot-scale air-pulsed } \\
\text { fluidized bed bioreactor } \\
\text { (continuous feed) }\end{array}$ & [59] \\
\hline Diclofenac, ibuprofen, naproxen, carbamazepine, and diazepam & Synthetic media & $\begin{array}{l}\text { Fungi } \\
\text { Phanerochaete chrysosporium }\end{array}$ & $\begin{array}{l}\text { Biodegradation } \\
\text { Biosorption }\end{array}$ & $\begin{array}{l}\text { Pilot-scale continuous stirred } \\
\text { tank reactor and fixed-bed } \\
\text { reactor }\end{array}$ & [64] \\
\hline Diclofenac, ketoprofen, and atenolol & Hospital wastewater & $\begin{array}{l}\text { Fungi } \\
\text { Pleurotus ostreatus }\end{array}$ & $\begin{array}{l}\text { Biodegradation } \\
\text { Adsorption }\end{array}$ & $\begin{array}{l}\text { Pilot-scale air-pulsed } \\
\text { fluidized-bed bioreactor } \\
\text { (continuous and batch feed) } \\
\text { Laboratory-scale batch assays }\end{array}$ & [67] \\
\hline
\end{tabular}


Table 2. Cont

\begin{tabular}{|c|c|c|c|c|c|}
\hline Compounds & Compounds Source & Strains & Removal Mechanisms & Technologies & Reference \\
\hline $17 \alpha$-ethinylestradiol and carbamazepine & Synthetic media & $\begin{array}{l}\text { Fungi } \\
\text { Pleurotus sp. P1 } \\
\text { Pleurotus ostreatus BS } \\
\text { (unidentified) basidiomycete } \\
\text { strain BNI }\end{array}$ & $\begin{array}{l}\text { Biodegradation } \\
\text { Adsorption }\end{array}$ & Laboratory-scale batch assays & [68] \\
\hline Tetracycline & Synthetic media & $\begin{array}{l}\text { Algae } \\
\text { Chlorella vulgaris }\end{array}$ & $\begin{array}{l}\text { Photodegradation } \\
\text { Biosorption }\end{array}$ & $\begin{array}{l}\text { Laboratory-scale batch assays } \\
\text { Pilot-scale high-rate algal } \\
\text { ponds (batch feed) }\end{array}$ & [164] \\
\hline Progesterone and norgestrel & Synthetic media & $\begin{array}{l}\text { Algae } \\
\text { Scenedesmus obliquus } \\
\text { Chlorella pyrenoidosa }\end{array}$ & $\begin{array}{l}\text { Biodegradation } \\
\text { Biosorption }\end{array}$ & Laboratory-scale batch assays & [168] \\
\hline Carbamazepine & Synthetic media & $\begin{array}{l}\text { Algae } \\
\text { Chlamydomonas Mexicana } \\
\text { Scenedesmus obliquus }\end{array}$ & $\begin{array}{l}\text { Biodegradation } \\
\text { Adsorption } \\
\text { Bioaccumulation }\end{array}$ & Laboratory-scale batch assays & [169] \\
\hline $\begin{array}{l}\text { Acetaminophen, ibuprofen, ketoprofen, naproxen, carbamazepine, } \\
\text { diclofenac, and triclosan }\end{array}$ & WWTP wastewater & $\begin{array}{l}\text { Algae } \\
\text { Lessonia nigrescens Bory } \\
\text { Macrocystis integrifolia Bory }\end{array}$ & $\begin{array}{l}\text { Biodegradation } \\
\text { Photodegradation } \\
\text { Biosorption }\end{array}$ & $\begin{array}{l}\text { Pilot-scale high-rate algal } \\
\text { ponds }\end{array}$ & [175] \\
\hline $17 \alpha$-ethinylestradiol, estrone, and $17 \beta$-estradiol & Synthetic media & $\begin{array}{l}\text { Algae } \\
\text { Anabaena cylindrical } \\
\text { Chlorococcus } \\
\text { Spirulina platensis, Chlorella } \\
\text { Scenedesmus quadricauda } \\
\text { Anaebena } \\
\text { (and duckweed Lemna) }\end{array}$ & $\begin{array}{l}\text { Biodegradation } \\
\text { Adsorption }\end{array}$ & $\begin{array}{l}\text { Laboratory-scale batch assays } \\
\text { Pilot-scale plug flow reactor } \\
\text { (continuous feed) }\end{array}$ & [180] \\
\hline Triclosan & Synthetic media & $\begin{array}{l}\text { Algae } \\
\text { Chlorella Pyrenoidosa }\end{array}$ & $\begin{array}{l}\text { Biodegradation } \\
\text { Biosorption }\end{array}$ & Laboratory-scale batch assays & [182] \\
\hline Tributyltin & Synthetic media & $\begin{array}{l}\text { Algae } \\
\text { Chlorella miniata } \\
\text { Chlorella sorokiniana } \\
\text { Scenedesmus dimorphus } \\
\text { Scenedesmus platydiscus }\end{array}$ & $\begin{array}{l}\text { Biodegradation } \\
\text { Adsorption } \\
\text { Absorption }\end{array}$ & Laboratory-scale batch assays & [188] \\
\hline Trimethoprim, sulfamethoxazole, and triclosan & Synthetic media & $\begin{array}{l}\text { Algae } \\
\text { Nannochloris Sp. }\end{array}$ & $\begin{array}{l}\text { Biodegradation } \\
\text { Adsorption }\end{array}$ & Laboratory-scale batch assays & [189] \\
\hline
\end{tabular}


Table 2. Cont

\begin{tabular}{|c|c|c|c|c|c|}
\hline Compounds & Compounds Source & Strains & Removal Mechanisms & Technologies & Reference \\
\hline $\begin{array}{l}\text { Diclofenac, ibuprofen, paracetamol, metoprolol, carbamazepine and } \\
\text { trimethoprim, estrone, } 17 \beta \text {-estradiol, and ethinylestradiol }\end{array}$ & Synthetic media & $\begin{array}{l}\text { Algae } \\
\text { Chlorella sorokiniana }\end{array}$ & $\begin{array}{l}\text { Biodegradation } \\
\text { Photolysis } \\
\text { Biosorption }\end{array}$ & Laboratory-scale batch assays & [190] \\
\hline$\beta$-estradiol and $17 \alpha$-ethynylestradiol & $\begin{array}{l}\text { WWTP anaerobic } \\
\text { sludge }\end{array}$ & $\begin{array}{l}\text { Algae } \\
\text { Selenastrum capricornutum } \\
\text { Chlamydomonas reinhardtii }\end{array}$ & $\begin{array}{l}\text { Biodegradation } \\
\text { Photodegradation } \\
\text { Adsorption }\end{array}$ & Laboratory-scale batch assays & [194] \\
\hline Sulfamethoxazole and sulfacetamide & Synthetic media & $\begin{array}{l}\text { Algae } \\
\text { Lessonia nigrescens Bory } \\
\text { Macrocystis integrifolia Bory }\end{array}$ & Adsorption & Laboratory-scale batch assays & [211] \\
\hline Penicillin G & Synthetic media & $\begin{array}{l}\text { Fungi } \\
\text { Rhizopus arrhizus }\end{array}$ & Biosorption & Laboratory-scale batch assays & [211] \\
\hline Chloramphenicol, acetyl salicylic acid, clofibric acid & Synthetic media & $\begin{array}{l}\text { Algae } \\
\text { Pterocladia capillacea } \\
\text { Ulva lactuca }\end{array}$ & Biosorption & Laboratory-scale batch assays & [225] \\
\hline Paracetamol & Synthetic media & $\begin{array}{l}\text { Algae } \\
\text { Alga Synechocystis sp. }\end{array}$ & Biosorption & $\begin{array}{l}\text { Laboratory-scale batch assays } \\
\text { Pilot-scale continuous } \\
\text { bubbling column } \\
\text { photobioreactor } \\
\text { (continuous feed) }\end{array}$ & [226] \\
\hline
\end{tabular}




\section{Conclusions and Future Perspectives}

The urban wastewater treatment industry is facing challenges, such as the fate of pharmaceuticals, which induce the development of wastewater treatment alternatives. In this review, an overview was drawn of fungi and algae potential to remove pharmaceuticals by bioremediation and biosorption processes from aquatic matrices. Algae present interesting advantages when compared with fungi, as they have a very fast growth and are able to remove both pharmaceuticals and nutrients, which is quite important since tertiary treatments are often needed for this purpose in domestic wastewater treatment. Moreover, this biomass is a valuable bioresource for the production of biofuel or high-value by-products. Bioremediation and biosorption studies proved to be eco-friendly and low-cost promising alternatives for pharmaceutical removal when compared to conventional methods applied for the same purpose. However, most of these studies remain at a laboratory-scale and are performed with synthetic media when it is well known that wastewaters are complex matrices that differ between WWTPs and can vary per geographical region. Only a few researchers are working on real field applications, since extensive research is still needed in order to understand the complexity of the processes, their dependence on physico-chemical and biological factors, and the mechanisms involved, in order to ensure high efficiencies for pharmaceutical removal. New knowledge in genetic engineering should be introduced in order to select and amplify the most effective algae or fungi strains for pharmaceutical removal. Several microorganisms contain key metabolic genes that could be introduced into other organisms. Genetically modified fungi and algae, armed with new or increased capacities for degrading various compounds, will likely have an important future in this field since it will allow these microorganisms to effectively remove pharmaceuticals from wastewaters and also allow their continuous use, considering legal limitations, as well as a pragmatic market and cost rationale.

Author Contributions: A.S. has gathered all the information for this review paper and was helped by C.D.-M., S.A.F. and O.M.F. in the organization of the information, synthesis and critical analysis.

Funding: This research was funded by the Associate Laboratory for Green Chemistry-LAQV which is financed by national funds from FCT/MCTES (UID/QUI/50006/2019) and co-financed by the ERDF under the PT2020 Partnership Agreement (POCI-01-0145-FEDER-007265). This research was funded also by the EU and FCT/UEFISCDI/FORMAS, in the frame of the collaborative international consortium REWATER financed under the ERA-NET Cofund WaterWorks2015 Call, this ERA-NET is an integral part of the 2016 Joint Activities developed by the Water Challenges for a Changing World Joint Program Initiative (Water JPI). Andreia Silva would like to thank FCT for her Ph.D. Grant SFRH/BD/138/780/2018.

Acknowledgments: The authors are greatly indebted to all financing sources.

Conflicts of Interest: The authors declare no conflict of interest.

\section{References}

1. Arnold, K.E.; Brown, A.R.; Ankley, G.T.; Sumpter, J.P. Medicating the environment: Assessing risks of pharmaceuticals to wildlife and ecosystems. Philos. Trans. R. Soc. B Boil. Sci. 2014, 369. [CrossRef] [PubMed]

2. Oulton, R.L.; Kohn, T.; Cwiertny, D.M. Pharmaceuticals and personal care products in effluent matrices: A survey of transformation and removal during wastewater treatment and implications for wastewater management. J. Environ. Monit. 2010, 12, 1956-1978. [CrossRef] [PubMed]

3. Paíga, P.; Santos, L.H.; Amorim, C.G.; Araújo, A.N.; Montenegro, M.C.; Pena, A.; Delerue-Matos, C. Pilot monitoring study of ibuprofen in surface waters of north of Portugal. Environ. Sci. Pollut. Res. 2013, 20, 2410-2420. [CrossRef] [PubMed]

4. Paíga, P.; Santos, L.H.M.L.M.; Ramos, S.; Jorge, S.; Silva, J.G.; Delerue-Matos, C. Presence of pharmaceuticals in the Lis river (Portugal): Sources, fate and seasonal variation. Sci. Total Environ. 2016, 573, 164-177. [CrossRef] [PubMed]

5. Pomati, F.; Castiglioni, S.; Zuccato, E.; Fanelli, R.; Vigetti, D.; Rossetti, C.; Calamari, D. Effects of a complex mixture of therapeutic drugs at environmental levels on human embryonic cells. Environ. Sci. Technol. 2006, 40, 2442-2447. [CrossRef] [PubMed] 
6. Boxall, A.B.A.; Rudd, M.A.; Brooks, B.W.; Caldwell, D.J.; Choi, K.; Hickmann, S.; Innes, E.; Ostapyk, K.; Staveley, J.P.; Verslycke, T.; et al. Pharmaceuticals and personal care products in the environment: What are the big questions? Environ. Health. Perspect. 2012, 120, 1221-1229. [CrossRef] [PubMed]

7. Directive 2000/60/EC of the European Parliament and of the Council of 23 October 2000 Establishing a Framework for Community Action in the Field of Water Policy. Available online: https://eur-lex.europa.eu/ resource.html?uri=cellar:5c835afb-2ec6-4577-bdf8-756d3d694eeb.0004.02/DOC_1\&format=PDF (accessed on 4 June 2019).

8. Decision No 2455/2001/EC of the European Parliament and of the Council of 20 November 2001 Establishing the List of Priority Substances in the Field of Water Policy, and Amending Directive 2000/60/EC. Available online: http://ec.europa.eu/environment/ecolabel/documents/prioritysubstances.pdf (accessed on 4 June 2019).

9. Directive 2008/105/EC of the European Parliament and of the Council of 16 December 2008 on Environmental Quality Standards in the Field of Water Policy, Amending and Subsequently Repealing Council Directives 82/176/EEC, 83/513/EEC, 84/156/EEC, 84/491/EEC, 86/280/EEC and Amending Directive 2000/60/EC of the European Parliament and of the Council. Available online: https://eur-lex.europa.eu/legal-content/EN/TXT/ PDF/?uri=CELEX:02008L0105-20130913\&from=DE (accessed on 4 June 2019).

10. Directive 2013/39/EU of the European Parliament and of the Council of 12 August 2013 Amending Directives 2000/60/EC and 2008/105/EC as Regards Priority Substances in the Field of Water Policy. Available online: http://eur-lex.europa.eu/LexUriServ/LexUriServ.do?uri=OJ:L:2013:226:0001:0017:EN:PDF (accessed on 4 June 2019).

11. Commission Implementing Decision (EU) 2015/495 of 20 March 2015 Establishing a Watch list of Substances for Union-Wide Monitoring in the Field of Water Policy Pursuant to Directive 2008/105/EC of the European Parliament and of the Council (Notified Under Document C(2015) 1756). Available online: https://eur-lex. europa.eu/legal-content/EN/TXT/PDF/?uri=CELEX:32015D0495\&from=PT (accessed on 4 June 2019).

12. Commission Implementing Decision (EU) 2018/840 of 5 June 2018 Establishing a Watch List of Substances for Union-Wide Monitoring in the Field of Water Policy Pursuant to Directive 2008/105/EC of the European Parliament and of the Council and repealing Commission Implementing Decision (EU) 2015/495. Available online: https://eur-lex.europa.eu/legal-content/EN/TXT/PDF/?uri=CELEX:32018D0840\&rid=7 (accessed on 4 June 2019).

13. Deziel, N. Pharmaceuticals in wastewater treatment plant effluent waters. Sch. Horiz. Univ. Minn. Morris Undergrad. J. 2014, 1, 12.

14. Moller, P.; Dulski, P.; Bau, M.; Knappe, A.; Pekdeger, A.; Sommer-von Jarmerasted, C. Anthropogenic gadolinium as a conservative tracer in hydrology. J. Geochem. Explor. 2000, 69, 409-414. [CrossRef]

15. Buerge, I.J.; Poiger, T.; Muller, M.D.; Buser, H.R. Caffeine, an anthropogenic marker for wastewater contamination of surface waters. Environ. Sci. Technol. 2003, 37, 691-700. [CrossRef]

16. Martínez-Carballo, E.; González-Barreiro, C.; Scharf, S.; Gans, O. Environmental monitoring study of selected veterinary antibiotics in animal manure and soils in Austria. Environ. Pollut. 2007, 148, 570-579. [CrossRef]

17. Kim, K.R.; Owens, G.; Kwon, S.I.; So, K.H.; Lee, D.B.; Ok, Y.S. Occurrence and Environmental Fate of Veterinary Antibiotics in the Terrestrial Environment. Water Air Soil Pollut. 2011, 214, 163-174. [CrossRef]

18. Ji, K.; Kim, S.; Han, S.; Seo, J.; Lee, S.; Park, Y.; Choi, K.; Kho, Y.L.; Kim, P.G.; Park, J. Risk Assessment of chlortetracycline, oxytetracycline, sulfamethazine, sulfathiazole and erythromycin in aquatic environment. Are the current environmental concentrations safe? Ecotoxicology 2012, 21, 2031-2050. [CrossRef] [PubMed]

19. Galichet, L.Y.; Moffat, A.C.; Osselton, M.D.; Widdop, B. Clarke's Analysis of Drugs and Poisons, 3rd ed.; Pharmaceutical Press: London, UK, 2004.

20. Verlicchi, P.; Al Aukidy, M.; Zambello, E. Occurrence of pharmaceutical compounds in urban wastewater: Removal, mass load and environmental risk after a secondary treatment-A review. Sci. Total Environ. 2012, 429, 123-155. [CrossRef] [PubMed]

21. Saussereau, E.; Lacroix, C.; Guerbet, M.; Cellier, D.; Spiroux, J.; Goullé, J.P. Determination of levels of current drugs in hospital and urban wastewater. Bull. Environ. Contam. Toxicol. 2013, 91, 171-176. [CrossRef] [PubMed]

22. Petrovic, M.; Gonzalez, S.; Barceló, D. Analysis and removal of emerging contaminants in wastewater and drinking water. Trends Anal. Chem. 2003, 22, 685-696. [CrossRef] 
23. Hörsing, M.; Ledin, A.; Grabic, R.; Fick, J.; Tysklind, M.; Jansen, J.L.C.; Andersen, H.R. Determination of sorption of seventy-five pharmaceuticals in sewage sludge. Water Res. 2011, 45, 4470-4482. [CrossRef] [PubMed]

24. Benotti, M.; Trenholm, R.A.; Vanderford, B.J.; Holady, H.C.; Stanford, B.D.; Snyder, S.A. Pharmaceuticals and endocrine disrupting compounds in U.S. drinking water. Environ. Sci. Technol. 2009, 43, 597-603. [CrossRef] [PubMed]

25. Joss, A.; Siegrist, H.; Ternes, T.A. Are we about to upgrade wastewater treatment for removing organic micropollutants? Water Sci. Technol. 2008, 57, 251-255. [CrossRef]

26. Wu, S.; Zhang, L.; Chen, J. Paracetamol in the Environment and its Degradation by Microorganisms. Appl. Microbiol. Biotechnol. 2012, 96, 875-884. [CrossRef]

27. Sahu, O. Reduction of organic and inorganic pollutant from waste water by algae. Int. Lett. Nat. Sci. 2014, 8, 1-8. [CrossRef]

28. Boopathy, R. Factors limiting bioremediation technologies. Bioresour. Technol. 2011, 74, 63-67. [CrossRef]

29. Kartheek, B.R.; Maheswaran, R.; Kumar, G.; Banu, G.S. Biodegradation of Pharmaceutical Wastes Using Different Microbial Strains. Int. J. Pharm. Biol. Arch. 2011, 2, 1401-1404.

30. Gillespie, I.M.M.; Philip, J.C. Bioremediation, an environmental remediation technology for the bioeconomy. Trends Biotechnol. 2013, 31, 329-332. [CrossRef] [PubMed]

31. Misal, S.A.; Lingojwar, D.P.; Shinde, R.M.; Gawai, K.R. Purification and characterization of azoreductase from alkaliphilic strain Bacillus badius. Process Biochem. 2011, 46, 1264-1269. [CrossRef]

32. Mashi, B.H. Biorremediation: Issues and Challenges. JORIND 2013, 11, 1596-8303.

33. Andrade, J.A.; Augusto, F.; Jardim, I.C.S.F. Biorremediação de solos contaminados por petróleo e seus derivados. Jornal Eclética Química 2010, 35. [CrossRef]

34. Gaylarde, C.C.; Bellinaso, M.L.; Manfilo, G.P. Biorremediação - aspetos biológicos e técnicos da biorremediação de xenobióticos. Biotecnol. Ciência Desenvolv. 2005, 34, 36-43.

35. Alexopoulos, C.J.; Mims, C.W.; Blackwell, M. Introductory Mycology, 4th ed.; John Wiley: New York, NY, USA, 1996.

36. Badia-Fabregat, M.; Lucas, D.; Gros, M.; Rodríguez-Mozaz, S.; Barceló, D.; Caminal, G.; Vicent, T. Identification of some factors affecting pharmaceutical active compounds (PhACs) removal in real wastewater. Case study of fungal treatment of reverse osmosis concentrate. J. Hazard. Mater. 2015, 283, 663-671. [CrossRef]

37. Zhang, Y.; Xie, J.; Liu, M.; Tian, Z.; He, Z.; van Nostrand, J.D.; Ren, L.; Zhou, J.; Yang, M. Microbial community functional structure in response to antibiotics in pharmaceutical wastewater treatment systems. Water Res. 2013, 47, 6298-6308. [CrossRef]

38. Durairaj, P.; Malla, S.; Nadarajan, S.P.; Lee, P.G.; Jung, E.; Park, H.H.; Kim, B.G.; Yun, H. Fungal cytochrome P450 monooxygenases of Fusarium oxysporum for the synthesis of $\omega$-hydroxy fatty acids in engineered Saccharomyces cerevisiae. Microb. Cell Fact. 2015, 14, 45. [CrossRef]

39. Jebapriya, G.R.; Gnanadoss, J.J. Bioremediation of textile dye using white-rot fungi: A review. Int. J. Curr. Res. Rev. 2013, 5, 1-13.

40. Morel, M.; Meux, E.; Mathieu, Y.; Thuillier, A.; Chibani, K.; Harvengi, L.; Jacquot, J.P.; Gelhaye, E. Xenomic networks variability and adaptation traits in wood decaying fungi. Microb. Biotechnol. 2013, 6, 248-263. [CrossRef] [PubMed]

41. Anastasi, A.; Tigini, V.; Varese, G.C. The bioremediation potential of different ecophysiological groups of fungi. In Fungi as Bioremediators; Goltapeh, E.M., Danesh, Y.R., Varma, A., Eds.; Springer-Verlag: New Delhi, India, 2013; Volume 32, pp. 29-49.

42. Spina, F.; Anastasi, A.; Prigione, V.; Tigini, V.; Varese, G.C. Biological treatment of industrial wastewaters: A fungal approach. Chem. Eng. Trans. 2012, 27, 175-180.

43. Crognale, S.; Federici, F.; Petruccioli, M. Enhanced separation of filamentous fungi by ultrasonic field: Possible usages in repeated batch processes. J. Biotechnol. 2002, 97, 191-197. [CrossRef]

44. Chisti, Y.; Moo-Young, M. On Bioreactors. In Encyclopedia of Physical Science and Technology; Meyers, R.A., Ed.; Academic Press: San Diego, CA, USA, 2002; Volume 2, pp. 247-271.

45. Zhong, J.J. Bioreactor Engineering. In Comprehensive Biotechnology; Elsevier B.V.: Amsterdam, The Netherlands, 2011; Volume 3, pp. 653-658. 
46. Marco-Urrea, E.; Perez-Trujillo, M.; Vicent, T.; Caminal, G. Ability of white-rot fungi to remove selected pharmaceuticals and identification of degradation products of ibuprofen by Trametes versicolor. Chemosphere 2009, 74, 765-772. [CrossRef]

47. Jelic, A.; Cruz-Morato, C.; Marco-Urrea, E.; Sarra, M.; Perez, S.; Vicent, T.; Petrovic, M.; Barcelo, D. Degradation of carbamazepine by Trametes versicolor in an air pulsed fluidized bed bioreactor and identification of intermediates. Water Res. 2012, 46, 955-964. [CrossRef]

48. Rodarte-Moralez, A.I.; Feijoo, G.; Moreira, M.T.; Lema, J.M. Degradation of selected pharmaceutical and personal care products (PPCPs) by white-rot fungi. World J. Microbial Biotechnol. 2011, 27, 1839-1846. [CrossRef]

49. Zhang, Y.; Geißen, S.U. Elimination of carbamazepine in a nonsterile fungal bioreactor. Bioresour. Technol. 2012, 112, 221-227. [CrossRef]

50. Cruz-Morató, C.; Ferrando-Climent, L.; Rodriguez-Mozaz, S.; Barceló, D.; Marco-Urrea, E.; Vicent, T.; Sarrà, M. Degradation of pharmaceuticals in non-sterile urban wastewater by Trametes versicolor in a fluidized bed bioreactor. Water Res. 2013, 47, 5200-5210. [CrossRef]

51. Nguyen, L.N.; Hai, F.I.; Yang, S.; Kang, J.; Leusch, F.D.L.; Roddick, F.; Price, W.E.; Nghiem, L.D. Removal of trace organic contaminants by an MBR comprising a mixed culture of bacteria and white-rot fungi. Bioresour. Technol. 2013, 148, 234-241. [CrossRef]

52. Cruz-Morató, C.; Lucas, D.; Llorca, M.; Rodriguez-Mozaz, S.; Gorga, M.; Petrovic, M.; Barceló, D.; Vicent, T.; Sarrà, M.; Marco-Urrea, E. Hospital wastewater treatment by fungal bioreactor: Removal efficiency for pharmaceuticals and endocrine disruptor compounds. Sci. Total Environ. 2014, 493, 365-376. [CrossRef] [PubMed]

53. Gros, M.; Cruz-Morato, C.; Marco-Urrea, E.; Longrée, P.; Singer, H.; Sarrà, M.; Hollender, J.; Vicent, T.; Rodriguez-Mozaz, S.; Barceló, D. Biodegradation of the X-ray contrast agent iopromide and the fluoroquinolone antibiotic ofloxacin by the white rot fungus Trametes versicolor in hospital wastewaters and identification of degradation products. Water Res. 2014, 60, 228-241. [CrossRef] [PubMed]

54. Nguyen, L.; Hai, F.i.; Yang, S.; Kang, J.; Leusch, F.; Roddick, F.; Price, W.E.; Nghiem, L.D. Removal of pharmaceuticals, steroid hormones, phytoestrogens, UV-filters, industrial chemicals and pesticides by Trametes versicolor: Role of biosorption and biodegradation. Int. Biodeterior. Biodegration 2014, 88, 169-175. [CrossRef]

55. Badia-Fabregat, M.; Lucas, D.; Pereira, M.A.; Alves, M.A.; Pennanen, T.; Fritze, H.; Rodríguez-Mozaz, S.; Barceló, D.; Vicent, T.; Caminal, G. Continuous fungal treatment of non-sterile veterinary hospital effluent: Pharmaceuticals removal and microbial community assessment. Appl. Microbiol. Biotechnol. 2016, 100, 2401-2415. [CrossRef] [PubMed]

56. Bodin, H.; Daneshvar, A.; Gros, M.; Hultberg, M. Effects of Biopellets Composed of Microalgae and Fungi on Pharmaceuticals Present at Environmentally Relevant Levels in Water. Ecol. Eng. J. Ecotechnol. 2016, 91, 169-172. [CrossRef]

57. Becker, D.; Rodriguez-Mozaz, S.; Insa, S.; Schoevaart, R.; Barceloó, D.; de Cazes, M.; Belleville, M.P.; Sanchez-Marcano, J.; Misovic, A.; Oehlmann, J.; et al. Removal of Endocrine Disrupting Chemicals in Wastewater by Enzymatic Treatment with Fungal Laccases. Org. Process Res. Dev. 2017, 21, 480-491. [CrossRef]

58. Blánquez, P.; Guieysse, B. Continuous biodegradation of $17 \beta$-estradiol and $17 \alpha$-ethynylestradiol by Trametes versicolor. J. Hazard. Mater. 2008, 150, 459-462. [CrossRef] [PubMed]

59. Rodriguez-Rodriguez, C.E.; García-Galán, M.J.; Blánquez, P.; Díaz-Cruz, M.S.; Barceló, D.; Caminal, G.; Vicent, T. Continuous degradation of a mixture of sulfonamides by Trametes versicolor and identification of metabolites from sulfapyridine and sulfathiazole. J. Hazard. Mater. 2012, 213-214, 347-354. [CrossRef]

60. Rodriguez-Rodriguez, C.E.; Marco-Urrea, E.; Caminal, G. Degradation of Naproxen and Carbamazepine in Spiked Sludge Slurry and Solid-Phase Trametes versicolor Systems. Bioresour. Technol. 2010, 101, 2259-2266. [CrossRef]

61. Marco-Urrea, E.; Perez-Trujillo, M.; Cruz-Morato, C.; Caminal, G.; Vicent, T. Degradation of the Drug Sodium Diclofenac Trametes versicolor Pellets and Identification of Some Intermediates by NMR. J. Hazard. Mater. 2010, 176, 836-842. [CrossRef] 
62. Marco-Urrea, E.; Perez-Trujillo, M.; Cruz-Morato, C.; Caminal, G.; Vicent, T. White-Rot Fungus-Mediated Degradation of the Analgesic Ketoprofen and Identification of Intermediates by HPLC-DAD-MS and NMR. Chemosphere 2010, 78, 474-481. [CrossRef] [PubMed]

63. Becker, D.; Varela Della Giustina, S.; Rodriguez-Mozaz, S.; Schoevaart, R.; Barcelo, D.; de Cazes, M.; Belleville, M.P.; Sanchez-Marcano, J.; de Gunzburg, J.; Couillerot, O.; et al. Removal of antibiotics in wastewater by enzymatic treatment with fungal laccase-Degradation of compounds does not always eliminate toxicity. Bioresour. Technol. 2016, 219, 500-509. [CrossRef] [PubMed]

64. Rodarte-Moralez, A.I.; Feijoo, G.; Moreira, M.T.; Lema, J.M. Operation of stirred tank reactors (STRs) and fixed-bed reactors (FBRs) with free and immobilized Phanerochaete chrysosporium for the continuous removal of pharmaceutical compounds. Biochem. Eng. J. 2012, 66, 38-45. [CrossRef]

65. Wen, X.; Jia, Y.; Li, J. Enzymatic Degradation of Tetracycline and Oxytetracycline Crude Manganese Peroxidase Prepared Phanerochaete Chrysosporium. J. Hazard. Mater. 2010, 177, 924-928. [CrossRef] [PubMed]

66. Watanabe, R.A.; Sales, P.T.F.; Campos, L.C.; Garcia, L.C.; Valadares, T.A.; Schimidt, M.C.; Santiago, M.F. Evaluation of the use of Pycnoporus sanguineus fungus for phenolics and genotoxicity decay of a pharmaceutical effluent treatment. Ambi-Agua Taubaté 2012, 7, 41-50.

67. Palli, L.; Castellet-Rovira, F.; Péerez-Trujillo, M.; Caniani, D.; Sarrá-Adroguer, M.; Gori, R. Preliminary Evaluation of Pleurotus ostreatus for the Removal of Selected Pharmaceuticals from Hospital Wastewater. Biotechnol. Prog. 2017, 33, 1529-1537. [CrossRef]

68. Santos, I.J.S.; Grossman, M.; Sartoratto, A.; Ponezi, A.; Durranta, L. Degradation of the Recalcitrant Pharmaceuticals Carbamazepine and $17 \alpha$-Ethinylestradiol by Ligninolytic fungi. Chem. Eng. Trans. 2012, 27, 169-174.

69. Esterhuizen-Londt, M.; Schwartz, K.; Pflugmacher, S. Using aquatic fungi for pharmaceutical bioremediation: Uptake of acetaminophen by Mucor hiemalis does not result in an enzymatic oxidative stress response. Fungal Biol. 2016, 120, 1249-1257. [CrossRef]

70. Buchicchio, A.; Bianco, G.; Sofo, A.; Masi, S.; Caniani, D. Biodegradation of carbamazepine and clarithromycin by Trichoderma harzianum and Pleurotus ostreatus investigated by liquid chromatography-high resolution tandem mass spectrometry (FTICR MS-IRMPD). Sci. Total Environ. 2016, 557, 733-739. [CrossRef]

71. Golan-Rozen, N.; Chefetz, B.; Ben-Ari, J.; Geva, J.; Hadar, Y. Transformation of the recalcitrant pharmaceutical compound carbamazepine by Pleurotus ostreatus: Role of cytochrome P450 monooxygenase and manganese peroxidase. Environ. Sci. Technol. 2011, 45, 6800-6805. [CrossRef]

72. Tran, N.H.; Urase, T.; Kusakabe, O. Biodegradation Characteristics of Pharmaceutical Substances by Whole Fungal Culture Trametes versicolor and its Laccase. J. Water Environ. Technol. 2010, 8, 125-140. [CrossRef]

73. Pointing, S.B. Feasibility of bioremediation by white-rot fungi. Appl. Microbiol. Biotechnol. 2001, 57, $20-33$. [PubMed]

74. Wesenberg, D.; Kyriakides, I.; Agathos, S.N. White-rot fungi and their enzymes for the treatment of industrial dye effluents. Biotechnol. Adv. 2003, 22, 161-187. [CrossRef] [PubMed]

75. Tortella, G.; Diez, M.; Durán, N. Fungal diversity and use in decomposition of environmental pollutants. Crit. Rev. Microbiol. 2005, 31, 197-212. [CrossRef] [PubMed]

76. Buchanan, I.D.; Nicell, J.A. Kinetics of peroxidase interactions in the presence of a protective additive. J. Chem. Technol. Biotechnol. 1998, 72, 23-32. [CrossRef]

77. Buchanan, I.D.; Han, Y.S. Assessment of the potential of Arthromyces ramosus peroxidase to remove phenol from industry wastewaters. Environ. Technol. 1999, 21, 545-552. [CrossRef]

78. Gasser, C.A.; Hommes, G.; Schaffer, A.; Corvini, P.F. Multi-catalysis reactions: New prospects and challenges of biotechnology to valorize lignin. Appl. Microbiol. Biotechnol. 2012, 95, 1115-1134. [CrossRef]

79. Kim, Y.J.; Nicell, J.A. Impact of reaction conditions on the laccase-catalyzed conversion of bisphenol A. Bioresour. Technol. 2006, 97, 1431-1442. [CrossRef]

80. Sayadi, S.; Ellouz, R. Roles of lignin peroxidase and manganese peroxidase from Phanerochaete chrysosporium in the decolorization of olive mill wastewaters. Appl. Environ. Microbiol. 1995, 61, 1098-1103.

81. Nguyen, L.N.; Hai, F.I.; Price, W.E.; Leusch, F.D.L.; Roddick, F.; McAdam, E.J.; Magram, A.F.; Long, D.; Nghiem, L.D. Continuous biotransformation of bisphenol A and diclofenac by laccase in an enzymatic membrane reactor. Int. Biodeterior. Biodegrad. 2014, 95, 25-32. [CrossRef] 
82. Nguyen, L.N.; Hai, F.I.; Price, W.E.; Leusch, F.D.; Roddick, F.; Ngo, H.H.; Guo, W.; Magram, S.F.; Nghiem, L.D. The effects of mediator and granular activated carbon addition on degradation of trace organic contaminants by an enzymatic membrane reactor. Bioresour. Technol. 2014, 167, 169-177. [CrossRef] [PubMed]

83. Nguyen, L.N.; Hai, F.I.; Kang, J.; Leusch, F.D.L.; Roddick, F.; Magram, S.F.; Price, W.E.; Nghiem, L.D. Enhancement of trace organic contaminant degradation by crude enzyme extract from Trametes versicolor culture: Effect of mediator type and concentration. J. Taiwan Inst. Chem. Eng. 2014, 45, 1855-1862. [CrossRef]

84. Nguyen, L.N.; Hai, F.I.; Dosseto, A.; Richardson, C.; Price, W.E.; Nghiem, L.D. Continuous adsorption and biotransformation of micropollutants by granular activated carbon-bound laccase in a packed-bed enzyme reactor. Bioresour. Technol. 2016, 210, 108-116. [CrossRef] [PubMed]

85. Nguyen, L.N.; van de Merwe, J.P.; Hai, F.I.; Leusch, F.D.L.; Kang, J.; Price, W.E.; Roddick, F.; Magram, S.F.; Nghiem, L.D. Laccase-syringaldehyde-mediated degradation of trace organic contaminants in an enzymatic membrane reactor: Removal efficiency and effluent toxicity. Bioresour. Technol. 2016, 200, 477-484. [CrossRef] [PubMed]

86. Rahmani, K.; Faramarzi, M.A.; Mahvi, A.H.; Gholami, M.; Esrafili, A.; Forootanfar, H.; Farzadkia, M. Elimination and detoxification of sulfathiazole and sulfamethoxazole assisted by laccase immobilized on porous silica beads. Int. Biodeterior. Biodegrad. 2015, 97, 107-114. [CrossRef]

87. Margot, J.; Bennati-Granier, C.; Maillard, J.; Blánquez, P.; Barry, D.A.; Holliger, C. Bacterial versus fungal laccase: Potential for micropollutant degradation. AMB Express 2013, 3, 63. [CrossRef] [PubMed]

88. Ji, C.; Hou, J.; Wang, K.; Zhang, Y.; Chen, V. Biocatalytic degradation of carbamazepine with immobilized laccase-mediator membrane hybrid reactor. J. Membr. Sci. 2016, 502, 11-20. [CrossRef]

89. Ji, C.; Hou, J.; Chen, V. Cross-linked carbon nanotubes-based biocatalytic membranes for micro-pollutants degradation: Performance, stability, and regeneration. J. Membr. Sci. 2016, 520, 869-880. [CrossRef]

90. Xu, R.; Tang, R.; Zhou, Q.; Li, F.; Zhang, B. Enhancement of catalytic activity of immobilized laccase for diclofenac biodegradation by carbon nanotubes. Chem. Eng. J. 2015, 262, 88-95. [CrossRef]

91. Touahar, I.E.; Haroune, L.; Ba, S.; Bellenger, J.P.; Cabana, H. Characterization of combined cross-linked enzyme aggregates from laccase, versatile peroxidase and glucose oxidase, and their utilization for the elimination of pharmaceuticals. Sci. Total Environ. 2014, 481, 90-99. [CrossRef]

92. Nair, R.R.; Demarche, P.; Agathos, S.N. Formulation and characterization of an immobilized laccase biocatalyst and its application to eliminate organic micropollutants in wastewater. New Biotechnol. 2013, 30, 814-823. [CrossRef] [PubMed]

93. Ding, H.; Wu, Y.; Zou, B.; Lou, Q.; Zhang, W.; Zhong, J.; Lu, L.; Dai, G. Simultaneous removal and degradation characteristics of sulfonamide, tetracycline, and quinolone antibiotics by laccase-mediated oxidation coupled with soil adsorption. J. Hazard. Mater. 2016, 307, 350-358. [CrossRef] [PubMed]

94. De Cazes, M.; Belleville, M.P.; Mougel, M.; Kellner, H.; Sanchez-Marcano, J. Characterization of laccase-grafted ceramic membranes for pharmaceuticals degradation. J. Membr. Sci. 2015, 476, 384-393. [CrossRef]

95. De Cazes, M.; Belleville, M.P.; Petit, E.; Llorca, M.; Rodríguez-Mozaz, S.; de Gunzburg, J.; Barceló, D.; Sanchez-Marcano, J. Design and optimization of an enzymatic membrane reactor for tetracycline degradation. Catal. Today 2014, 236, 146-152. [CrossRef]

96. Llorca, M.; Rodríguez-Mozaz, S.; Couillerot, O.; Panigoni, K.; de Gunzburg, J.; Bayer, S.; Czaja, R.; Barceló, D. Identification of new transformation products during enzymatic treatment of tetracycline and erythromycin antibiotics at laboratory scale by an on-line turbulent flow liquid-chromatography coupled to a high resolution mass spectrometer LTQ-Orbitrap. Chemosphere 2015, 119, 90-98. [CrossRef] [PubMed]

97. Singh, R.; Sidhu, S.S.; Zhang, H.; Huang, Q. Removal of sulfadimethoxine in soil mediated by extracellular oxidoreductases. Environ. Sci. Pollut. Res. 2015, 22, 16868-16874. [CrossRef] [PubMed]

98. Singh, D.; Rawat, S.; Waseem, M.; Gupta, S.; Lynn, A.; Nitin, M.; Ramchiary, N.; Sharm, K.K. Molecular modeling and simulation studies of recombinant laccase from Yersinia enterocolitica suggests significant role in the biotransformation of non-steroidal anti-inflammatory drugs. Biochem. Biophys. Res. Commun. 2016, 469, 306-312. [CrossRef]

99. Li, X.; Xu, Q.M.; Cheng, J.S.; Yuan, Y.J. Improving the bioremoval of sulfamethoxazole and alleviating cytotoxicity of its biotransformation by laccase producing system under coculture of Pycnoporus sanguineus and Alcaligenes Faecalis. Bioresour. Technol. 2016, 220, 333-340. [CrossRef] 
100. Chen, Y.; Stemple, B.; Kumar, M.; Wei, N. Cell surface display fungal laccase as a renewable biocatalyst for degradation of persistent micropollutants bisphenol A and sulfamethoxazole. Environ. Sci. Technol. 2016, 50, 8799-8808. [CrossRef]

101. Hofmann, U.; Schlosser, D. Biochemical and physicochemical processes contributing to the removal of endocrine-disrupting chemicals and pharmaceuticals by the aquatic ascomycete Phoma sp. UHH 5-1-03. Appl. Microbiol. Biotechnol 2016, 100, 2381-2399. [CrossRef]

102. Shi, L.; Ma, F.; Han, Y.; Zhang, X.; Yu, H. Removal of sulfonamide antibiotics by oriented immobilized laccase on $\mathrm{Fe}_{3} \mathrm{O}_{4}$ nanoparticles with natural mediators. J. Hazard. Mater. 2014, 279, 203-211. [CrossRef] [PubMed]

103. Margot, J.; Copin, P.J.; von Gunten, U.; Barry, D.A.; Holliger, C. Sulfamethoxazole and isoproturon degradation and detoxification by a laccase-mediator system: Influence of treatment conditions and mechanistic aspects. Biochem. Eng. J. 2015, 103, 47-59. [CrossRef]

104. Martinez, D.; Larrondo, L.F.; Putnam, N.; Gelpke, M.D.S.; Huang, K.; Chapman, J.; Helfenbein, K.G.; Ramaiya, P.; Detter, J.C.; Larimer, F.; et al. Genome sequence of lignocellulose degrading fungus Phanerochaete chrysosporium strain RP78. Nat. Biotechnol. 2004, 22, 695-700. [CrossRef] [PubMed]

105. Fabbrini, M.; Galli, C.; Gentili, P. Comparing the catalytic efficiency of some mediators of laccase. J. Mol. Catal. B Enzym. 2002, 16, 231-240. [CrossRef]

106. Cañas, A.I.; Camarero, S. Laccases and their natural mediators: Biotechnological tools for sustainable eco-friendly processes. Biotechnol Adv. 2010, 28, 694-705. [CrossRef]

107. Hu, M.R.; Chao, Y.P.; Zhang, G.Q.; Xue, Z.Q.; Qian, S. Laccase mediator system in the decolorization of different types of recalcitrant dyes. J. Ind. Microbiol. Biotechnol. 2009, 36, 45-51. [CrossRef] [PubMed]

108. Wong, D.W. Structure and action mechanism of ligninolytic enzymes. Appl. Biochem. Biotechnol. 2009, 157, 174-209. [CrossRef]

109. Morozova, O.V.; Shumakovich, G.P.; Shleev, S.V.; Yaropolov, Y.I. Laccase-mediator systems and their applications: A review. Appl. Biochem. Microbiol. 2007, 43, 523-535. [CrossRef]

110. Pogni, R.; Baratto, M.C.; Sinicropi, A.; Basosi, R. Spectroscopic and computational characterization of laccases and their substrate radical intermediates. Cell Mol. Life Sci. 2015, 72, 885-896. [CrossRef]

111. Weng, S.S.; Liu, S.M.; Lai, H.T. Application parameters of laccase mediator systems for treatment of sulfonamide antibiotics. Bioresour. Technol. 2013, 141, 152-159. [CrossRef]

112. Kurniawati, S.; Nicell, J.A. Efficacy of mediators for enhancing the laccase-catalyzed oxidation of aqueous phenol. Enzyme Microb. Technol. 2007, 41, 353-361. [CrossRef]

113. Fillat, U.; Prieto, A.; Camarero, S.; Martínez, Á.T.; Martínez, M.J. Biodeinking of flexographic inks by fungal laccases using synthetic and natural mediators. Biochem. Eng. J. 2012, 67, 97-103. [CrossRef]

114. Ashe, B.; Nguyen, L.N.; Hai, F.I.; Lee, D.J.; van de Merwe, J.P.; Leusch, F.D.L.; Price, W.E.; Nghiem, L.D. Impacts of redox-mediator type on trace organic contaminants degradation by laccase: Degradation efficiency, laccase stability and effluent toxicity. Int. Biodeterior. Biodegrad. 2016, 113, 169-176. [CrossRef]

115. Verma, P.; Madamwar, D. Production of lignolytic enzymes for dye decolorization by co-cultivation of white rot fungi Pleurotus ostreatus and Phanerochaete chrysosporium under solid state fermentation. Appl. Biochem. Biotechnol 2002, 102-103, 109-118. [CrossRef]

116. Zhang, Y.; Geißen, S.U. In Vitro Degradation of Carbamazepine and Diclofenac Crude Lignin Peroxidase. J. Hazard. Mater. 2010, 176, 1089-1092. [CrossRef] [PubMed]

117. Kennedy, J.F.; Cabral, J.M.S. Enzyme Immobilization. In Biotechnology; Rehm, H.J., Reed, G., Eds.; VCH: Weinheim, Germany, 1987; pp. 347-404.

118. Asif, M.B.; Hai, F.I.; Singh, L.; Price, W.E.; Nghiem, L.D. Degradation of Pharmaceuticals and Personal Care Products by White-Rot Fungi-a Critical Review. Curr. Pollut. Rep. 2017, 3, 88-103. [CrossRef]

119. Yang, S.; Hai, F.I.; Nghiem, L.D.; Nguyen, L.N.; Roddick, F.; Price, W.E. Removal of bisphenol A and diclofenac by a novel fungal membrane bioreactor operated under non-sterile conditions. Int. Biodeterior. Biodegrad. 2013, 85, 483-490. [CrossRef]

120. Suda, T.; Hata, T.; Kawai, S.; Okamura, H.; Nishida, T. Treatment of tetracycline antibiotics by laccase in the presence of 1-hydroxybenzotriazole. Bioresour. Technol. 2012, 103, 498-501. [CrossRef]

121. Joutey, N.T.; Bahafid, W.; Sayel, H.; Ghachtouli, N.E. Biodegradation: Involved microorganisms and genetically engineered microorganisms. In Biodegradation—Life of Science; Chamy, R., Rosenkranz, F., Eds.; InTechOpen: London, UK, 2013; p. 305.

122. Dujon, B. The yeast genome project: What did we learn? Trends Genet 1996, 12, 263-270. [CrossRef] 
123. Wood, V.; Gwilliam, R.; Rajandream, M.A.; Lyne, M.; Lyne, R.; Stewart, A.; Sgouros, J.; Peat, N.; Hayles, J.; Baker, S.; et al. The genome sequence of Schizosaccharomyces pombe. Nature 2002, 415, 871-880. [CrossRef]

124. Martinez, M.; Bernal, P.; Almela, C.; Velez, D.; Garcia-Agustin, P.; Serrano, R. An engineered plant that accumulates higher levels of heavy metals than Thlaspi caerulescens, with yields of 100 times more biomass in mine soils. Chemosphere 2006, 64, 478-485. [CrossRef] [PubMed]

125. Nam, J.M.; Fujita, Y.; Arai, T.; Kondo, A.; Morikawa, Y.; Okada, H.; Ueda, M.; Tanaka, A. Construction of engineered yeast with the ability of binding to cellulose. J. Mol. Catal. B Enzym. 2002, 17, 197-202. [CrossRef]

126. Balcázar-López, E.; Méndez-Lorenzo, L.H.; Batista-García, R.A.; Esquivel-Naranjo, U.; Ayala, M.; Kumar, V.V.; Savary, O.; Cabana, H.; Herrera-Estrella, A.; Folch-Mallol, J.L. Xenobiotic compounds degradation by heterologous expression of a Trametes sanguineus laccase in Trichoderma atroviride. PLoS ONE 2016, 11, e0147997. [CrossRef] [PubMed]

127. Sze, P. A Biology of the Algae, 3rd ed.; WCB/McGraw-Hill: Boston, MA, USA, 1998.

128. Ruggiero, M.A.; Gordon, D.P.; Orrell, T.M.; Bailly, N.; Bourgoin, T.; Brusca, R.C.; Cavalier-Smith, T.; Guiry, M.D.; Kirk, P.M. Correction: A Higher Level Classification of All Living Organisms. PLoS ONE 2015, 10, e0130114. [CrossRef] [PubMed]

129. Subashchandrabose, S.R.; Ramakrishnam, B.; Megharaj, M.; Venkateswarlu, K.; Naidu, R.R. Mixotrophic Cyanobacteria and microalgae as distinctive biological agents for organic pollutant degradation. Environ. Int. 2013, 51, 59-72. [CrossRef] [PubMed]

130. Fu, W.; Chaiboonchoe, A.; Khraiwesh, B.; Nelson, D.R.; Al-Khairy, D.; Mystikou, A.; Alzahmi, A.; Salehi-Ashtiani, K. Algal Cell Factories: Approaches, Applications, and Potentials. Mar. Drugs 2016, 14, 225. [CrossRef]

131. Osundeko, O.; Dean, A.P.; Davies, H.; Pittman, J.K. Acclimation of microalgae to wastewater environments involves increased oxidative stress tolerance activity. Plant Cell Physiol. 2014, 55, 1848-1857. [CrossRef]

132. Cho, K.; Lee, C.H.; Ko, K. Use of phenol-induced oxidative stress acclimation to stimulate cell growth and biodiesel production by the oceanic microalga Dunaliella salina. Algal Res. 2016, 17, 61-66. [CrossRef]

133. Xiong, J.Q.; Kurade, M.B.; Jeon, B.H. Biodegradation of levofloxacin by an acclimated freshwater alga Chlorella vulgaris. Chem. Eng. J. 2017, 313, 1251-1257. [CrossRef]

134. Rehnstam-Holm, A.S.; Godhe, A. Genetic Engineering of Algal Species. In Biotechnology; Doelle, H.W., Ed.; Encyclopedia of Life Support Systems (EOLSS) Publishers: Oxford, UK, 2003.

135. Muñoz, R.; Guieysse, B. Algal-bacterial processes for the treatment of hazardous contaminants: A review. Water Res. 2006, 40, 2799-2815. [CrossRef]

136. Office of Water, Wastewater Management Fact Sheet, Energy Conservation; EPA 832-F-06-024; U.S. Environmental Protection Agency: Washington, DC, USA, 2006; p. 7.

137. Oswald, W.J.; Golueke, C.G. Biological transformation of solar energy. Adv. Appl. Microbiol. 1960, 2, $223-262$. [CrossRef] [PubMed]

138. Polprasert, C.; Dissanayake, M.; Thanh, N. Bacterial Die-Off Kinetics in Waste Stabilization Ponds. Water Pollut. Control Fed. 1983, 55, 285-296. [CrossRef]

139. Pienkos, P.; Darzins, A. The promise and challenges of microalgal-derived biofuels. Biofuels Bioprod. Biorefin. 2009, 431-440. [CrossRef]

140. Becker, E.W. Micro-algae for human and animal consumption. In Micro-Algal Biotechnology; Borowitzka, M.A., Borowitzka, L.J., Eds.; Cambridge University Press: Cambridge, UK, 1988; pp. 222-256.

141. Ugwu, C.U.; Aoyagi, H.; Uchiyama, H. Photobioreactors for mass cultivation of algae. Bioresour. Technol. 2008, 99, 4021-4028. [CrossRef] [PubMed]

142. Chisti, Y. Biodiesel from microalgae. Biotechnol. Adv. 2007, 25, 294-306. [CrossRef] [PubMed]

143. Garcia, J.; Green, B.F.; Lundquist, T.; Mujeriego, R.; Hernández-Mariné, M.; Oswald, W.J. Long term diurnal variations in contaminant removal in high rate ponds treating urban wastewater. Bioresour. Technol. 2006, 97, 1709-1715. [CrossRef] [PubMed]

144. Harun, R.; Singh, M.; Forde, G.M.; Danquah, M.K. Bioprocess engineering of microalgae to produce a variety of consumer products. Renew. Sustain. Energy Rev. 2010, 14, 1037-1047. [CrossRef]

145. Picot, B.; Moersidik, S.; Casellas, C.; Bontoux, J. Using diurnal variations in a high rate algal pond for management pattern. Water Sci. Technol. 1993, 28, 169-175. [CrossRef]

146. Singh, S.P.; Singh, P. Effect of temperature and light on the growth of algae species: A review. Renew. Sustain. Energy Rev. 2015, 50, 431-444. [CrossRef] 
147. Chen, C.Y.; Yeh, K.L.; Aisyah, R.; Lee, D.J.; Chang, J.S. Cultivation, photobioreactor design and harvesting of microalgae for biodiesel production: A critical review. Bioresour. Technol. 2011, 102, 71-81. [CrossRef]

148. Eriksen, N.T. The technology of microalgal culturing. Biotechnol. Lett. 2008, 30, 1525-1536. [CrossRef] [PubMed]

149. Wiley, P.E.; Brenneman, K.J.; Jacobson, A.E. Improved Algal Harvesting Using Suspended Air Flotation. Water Environ. Res. 2009, 81, 702-708. [CrossRef] [PubMed]

150. Akhtar, N.; Iqbal, J.; Iqbal, M. Enhancement of lead (II) biosorption by microalgal biomass immobilized onto loofa (Luffa cylindrica) sponge. Eng. Life Sci. 2004, 4, 171-178. [CrossRef]

151. Mallick, N. Biotechnological potential of immobilized algae for wastewater N, P and metal removal: A review. Biometals 2002, 15, 377-390. [CrossRef] [PubMed]

152. Amaro, H.M.; Guedes, A.C.; Malcata, F.X. Advances and perspectives in using microalgae to produce biodiesel. Appl. Energy 2011, 88, 3402-3410. [CrossRef]

153. Schenk, P.M.; Thomas-Hall, S.R.; Stephens, E.; Marx, U.C.; Mussgnug, J.H.; Posten, C.; Kruse, O.; Hankamer, B. Second generation biofuels: High-efficiency microalgae for biodiesel production. Bioenergy Res. 2008, 1, $20-43$. [CrossRef]

154. Taylor, R.L.; Rand, J.D.; Caldwell, G.S. Treatment with algae extracts promotes flocculation, and enhances growth and neutral lipid content in Nannochloropsis oculata-A candidate for biofuel production. Mar. Biotechnol. 2012, 6, 774-781. [CrossRef]

155. Van Den Hende, S.; Vervaeren, H.; Saveyn, H.; Maes, G.; Boon, N. Microalgal bacterial floc properties are improved by a balanced inorganic/organic carbon ratio. Biotechnol. Bioeng. 2011, 108, 549-558. [CrossRef]

156. Su, Y.; Mennerich, A.; Urban, B. Municipal wastewater treatment and biomass accumulation with a wastewater-born and settleable algal-bacterial culture. Water Res. 2011, 45, 3351-3358. [CrossRef]

157. Zhou, W.; Cheng, Y.; Li, Y.; Wan, Y.; Liu, Y.; Lin, X.; Ruan, R. Novel fungal palletization-assisted technology for algae harvesting and wastewater treatment. Appl. Biochem. Biotechnol. 2012, 167, 214-228. [CrossRef]

158. Zhang, J.G.; Hu, B.A. novel method to harvest microalgae via co-culture of filamentous fungi to form cell pellets. Bioresour. Technol. 2012, 114, 529-535. [CrossRef] [PubMed]

159. Gultom, S.O.; Hu, B. Review of microalgae harvesting via co-pelletization with filamentous fungus. Energies 2013, 6, 5921-5939. [CrossRef]

160. Wittenberg, K.M. Preservation of high-moisture hay in storage through the use of forage additives. Can. J. Anim. Sci. 1991, 71, 429-437. [CrossRef]

161. Milledge, J.J.; Heaven, S.A. review of the harvesting of micro-algae for biofuel production. Rev. Environ. Sci. Biotechnol. 2013, 12, 165-178. [CrossRef]

162. Olguin, E.J. Dual purpose microalgae-bacteria-based systems that treat wastewater and produce biodiesel and chemical products within a biorefinery. Biotechnol. Adv. 2012, 30, 1031-1046. [CrossRef] [PubMed]

163. Matamoros, V.; Uggetti, E.; García, J.; Bayona, J.M. Assessment of the mechanisms involved in the removal of emerging contaminants by microalgae from wastewater: A laboratory scale study. J. Hazard. Mater. 2015, 301, 197-205. [CrossRef] [PubMed]

164. De Godos, I.; Muñoz, R.; Guieysse, B. Tetracycline removal during wastewater treatment in high-rate algal ponds. J. Hazard. Mater 2012, 229-230, 446-449. [CrossRef]

165. Harms, H.; Schlosser, D.; Wick, L.Y. Untapped potential: Exploiting fungi in bioremediation of hazardous chemicals. Nat. Rev. Microbiol. 2011, 9, 177-192. [CrossRef]

166. Joss, A.; Zabczynski, S.; Gobel, A.; Hoffmann, B.; Loffler, D.; McArdell, C.S.; Ternes, T.A.; Thomsen, A.; Siegrist, H. Biological degradation of pharmaceuticals in municipal wastewater treatment: Proposing a classification scheme. Water Res. 2006, 40, 1686-1696. [CrossRef]

167. Kumar, M.S.; Kabra, A.N.; Min, B.; El-Dalatony, M.M.; Xiong, J.; Thajuddin, N.; Lee, D.S.; Jeon, B.H. Insecticides induced biochemical changes in freshwater microalga Chlamydomonas mexicana. Environ. Sci. Pollut. Res. 2016, 23, 1091-1099. [CrossRef]

168. Peng, F.Q.; Ying, G.G.; Yang, B.; Liu, S.; Lai, H.J.; Liu, Y.S.; Chen, Z.F.; Zhou, G.J. Biotransformation of progesterone and norgestrel by two freshwater microalgae (Scenedesmus obliquus and Chlorella pyrenoidosa): Transformation kinetics and products identification. Chemosphere 2014, 95, 581-588. [CrossRef] [PubMed]

169. Xiong, J.Q.; Kurade, M.B.; Abou-Shanab, R.A.I.; Ji, M.K.; Choi, J.J.O.; Jeon, B.H. Biodegradation of carbamazepine using freshwater microalgae Chlamydomonas mexicana and Scenedesmus obliquus and the determination of its metabolic fate. Bioresour. Technol. 2016, 205, 183-190. [CrossRef] [PubMed] 
170. Maes, H.M.; Maletz, S.X.; Ratte, H.T.; Hollender, J.; Schaeffer, A. Uptake, elimination, and biotransformation of $17 \alpha$-ethinylestradiol by the freshwater alga Desmodesmus subspicatus. Environ. Sci. Technol. 2014, 48, 12354-12361. [CrossRef] [PubMed]

171. Ding, T.; Yang, M.; Zhang, J.; Yang, B.; Lin, K.; Li, J.; Gan, J. Toxicity, degradation and metabolic fate of ibuprofen on freshwater diatom Navicula sp. J. Hazard. Mater. 2017, 330, 127-134. [CrossRef] [PubMed]

172. Thies, F.T.; Backhaus, T.; Bossmann, B.; Grimme, L.H. Xenobiotic biotransformation in unicellular green algae. Plant Physiol. 1996, 112, 361-370. [CrossRef] [PubMed]

173. Xiong, J.Q.; Kurade, M.B.; Patil, D.V.; Jang, M.; Paeng, K.J.; Jeon, B.H. Biodegradation and metabolic fate of levofloxacin via a freshwater green alga, Scenedesmus obliquus in synthetic saline wastewater. Algal Res. 2017, 25, 54-61. [CrossRef]

174. Flemming, H.C.; Wingender, J. The biofilm matrix. Nat. Rev. Microbiol. 2010, 8, 632-633. [CrossRef] [PubMed]

175. Matamoros, V.; Gutiérrex, R.; Ferrer, I.; García, J.; Bayona, J.M. Capability of microalgae-based wastewater treatment systems to remove emerging organic contaminants: A pilot-scale study. J. Hazard. Matter. 2015, 288, 34-42. [CrossRef] [PubMed]

176. Díaz-Garduño, B.; Pintado-Herrera, M.G.; Biel-Maeso, M.; Rueda-Márquez,J.J.; Lara-Martín, P.A.; Perales, J.A.; Manzano, M.A.; Garrido-Pérez, C.; Martín-Díaz, M.L. Environmental Risk Assessment of Effluents as a Whole Emerging Contaminant-Efficiency of Alternative Tertiary Treatments for Wastewater Depuration. Water Res. 2017, 119, 136-149. [CrossRef] [PubMed]

177. Hom-Diaz, A.; Jaén-Gil, A.; Bello-Laserna, I.; Rodríguez-Mozaz, S.; Vicent, T.; Barceló, D.; Blánquez, P. Performance of a Microalgal Photobioreactor Treating Toilet Wastewater: Pharmaceutically Active Compound Removal and Biomass Harvesting. Sci. Total Environ. 2017, 592, 1-11. [CrossRef] [PubMed]

178. Gentili, F.G.; Fick, J. Algal cultivation in urban wastewater: An efficient way to reduce pharmaceutical pollutants. J. Appl. Phycol. 2017, 29, 255-262. [CrossRef] [PubMed]

179. Lai, K.M.; Scrimshaw, M.D.; Lester, J.N. Biotransformation and Bioconcentration of Steroid Estrogens by Chlorella Vulgaris. Appl. Environ. Microbiol. 2002, 68, 859-864. [CrossRef]

180. Shi, W.; Wang, L.; Rousseau, D.P.L.; Lens, P.N.L. Removal of Estrone, $17 \alpha$-Ethinylestradiol, and $17 \beta$-Estradiol in Algae and Duckweed-Based Wastewater Treatment Systems. Environ. Sci. Pollut. Res. 2010, 17, 824-833. [CrossRef] [PubMed]

181. Mani, D.; Kumar, C. Biotechnological advances in bioremediation of heavy metals contaminated ecosystems: An overview with special reference to phytoremediation. Int. J. Environ. Sci. Technol. 2014, 11, 843-872. [CrossRef]

182. Wang, S.; Wang, X.; Poon, K.; Wang, Y.; Li, S.; Liu, H.; Lin, S.; Cai, Z. Removal and Reductive Dechlorination of Triclosan by Chlorella Pyrenoidosa. Chemosphere 2013, 92, 1498-1505. [CrossRef]

183. Chen, J.; Zheng, F.; Guo, R. Algal feedback and removal efficiency in a sequencing batch reactor algae process (SBAR) to treat the antibiotic cefradine. PLoS ONE 2015, 10, e0133273. [CrossRef] [PubMed]

184. Greca, M.D.; Pinto, G.; Pistillo, P.; Pollio, A.; Previtera, L.; Temussi, F. Biotransformation of ethinylestradiol by microalgae. Chemosphere 2008, 70, 2047-2053. [CrossRef]

185. Zhou, G.J.; Ying, G.G.; Liu, S.; Zhou, L.J.; Chen, Z.F.; Peng, F.Q. Simultaneous removal of inorganic and organic compounds in wastewater by freshwater green microalgae. Environ. Sci. 2014, 16, 2018-2027. [CrossRef]

186. Escapa, C.; Coimbra, R.N.; Paniagua, S.; García, A.I.; Otero, M. Nutrients and pharmaceuticals removal from wastewater by culture and harvesting of Chlorella sorokiniana. Bioresour. Technol. 2015, 185, 276-284. [CrossRef]

187. Santos, C.E.; de Coimbra, R.N.; Bermejo, S.P.; Pérez, A.I.G.; Cabero, M.O. Comparative Assessment of Pharmaceutical Removal from Wastewater by the Microalgae Chlorella sorokiniana, Chlorella vulgaris and Scenedesmus obliquus. In Biological Wastewater Treatment and Resource Recovery; Farooq, R., Ahmad, Z., Eds.; IntechOpen: London, UK, 2017. [CrossRef]

188. Tam, N.F.Y.; Chong, A.M.Y.; Wong, Y.S. Removal of Tributyltin (TBT) by Live and Dead Microalgal Cells. Mar. Pollut. Bull. 2002, 45, 362-371. [CrossRef]

189. Bai, X.; Acharya, K. Removal of Trimethoprim, Sulfamethoxazole, and Triclosan by the Green Alga Nannochloris Sp. J. Hazard. Mater. 2016, 315, 70-75. [CrossRef] [PubMed]

190. De Wilt, A.; Butkovskyi, A.; Tuantet, K.; Leal, L.H.; Fernandes, T.V.; Langenhoff, A.; Zeeman, G. Micropollutant Removal in an Algal Treatment System Fed with Source Separated Wastewater Streams. J. Hazard. Mater. 2016, 304, 84-92. [CrossRef] [PubMed] 
191. Dzomba, P.; Kugara, J.; Mukunyaidze, V.V.; Zaranyika, M.F. Biodegradation of tetracycline antibacterial using green algal species collected from municipal and hospital effluents. Der. Chem. Sin. 2015, 6, 27-33.

192. Escapa, C.; Coimbra, R.N.; Paniagua, S.; García, A.I.; Otero, M. Removal of pharmaceuticals from industrial wastewaters by microalgae culture. In Proceedings of the International Conference on Industrial Waste and Wastewater Treatment and Valorisation, Athens, Greece, 21-23 May 2015.

193. Xiong, J.Q.; Kurade, M.B.; Kim, J.R.; Roh, H.S.; Jeon, B.H. Ciprofloxacin toxicity and its co-metabolic removal in a freshwater microalgae Chlamydomonas mexicana. J. Hazard. Mater. 2017, 323, 212-219. [CrossRef] [PubMed]

194. Hom-Diaz, A.; Llorca, M.; Rodríguez-Mozaz, S.; Vicent, T.; Barceló, D.; Blánquez, P. Microalgae cultivation on wastewater digestate: $\beta$-estradiol and $17 \alpha$-ethynylestradiol degradation and transformation products identification. J. Environ. Manag. 2015, 155, 106-113. [CrossRef]

195. Toscano, M.D.; De Maria, L.; Lobedanz, S.; Ostergaard, L.H. Optimization of a small laccase by active-site redesign. ChemBioChem 2013, 14, 1209-1211. [CrossRef]

196. Gadd, G.M. Biosorption: Critical review of scientific rationale, environmental importance and significance for pollution treatment. J. Chem. Technol. Biotechnol. 2009, 84, 13-28. [CrossRef]

197. Michalak, I.; Chojnacka, K.; Witek-Krowiak, A. State of the art for the biosorption process-A review. Appl. Biochem. Biotechnol. 2013, 170, 1389-1416. [CrossRef]

198. Babel, S.; Kurniawan, T.A. Low-cost adsorbents for heavy metals uptake from contaminated water: A review. J. Hazard. Mater. 2003, 97, 219-243. [CrossRef]

199. Dutta, M.; Duttam, N.N.; Bhattacharya, K.G. Aqueous phase adsorption of certain beta-lactam antibiotics onto polymeric resins and activated carbon. Sep. Purif. Technol. 1999, 16, 213-224. [CrossRef]

200. Aitcheson, S.J.; Arnett, J.; Murray, K.R.; Zhang, J. Removal of aquaculture therapeutants by carbon adsorption. 1. Equilibrium adsorption behaviour of single components. Aquaculture 2000, 183, 269-284. [CrossRef]

201. Swedish Environmental Protection Agency, Advanced Wastewater Treatment for Separation and Removal of Pharmaceutical Residues and Other Hazardous Substances-Needs, Technologies and Impacts; REPORT 6803; Naturvårdsverket: Stockholm, Sweden, 2017.

202. Bailey, S.E.; Olin, T.J.; Bricka, M.; Adrian, D.D. A review of potentially low-cost adsorbents for heavy metals. Water Res. 1999, 33, 2469-2479. [CrossRef]

203. Tsezos, M.; Bell, J.P. Comparison of the biosorption and desorption of hazardous organic pollutants by live and dead biomass. Water Res. 1989, 23, 561-568. [CrossRef]

204. Stumm, W.; Morgan, J.J. Aquatic Chemistry: Chemical Equilibria and Rates in Natural Waters, 3rd ed.; John Wiley \& Sons: New York, NY, USA, 1996.

205. Gow, N.A.R.; Gadd, G.M. The Growing Fungus; Chapman and Hall: London, UK, 1995.

206. Gadd, G.M. Interactions of fungi with toxic metals. New. Phytol. 1993, 124, 25-60. [CrossRef]

207. Aksu, Z. Application of biosorption of the removal of organic pollutants: A review. Process Biochem. 2005, 40, 997-1026. [CrossRef]

208. Gadd, G.M.; Mowll, J.L. Copper uptake by yeast-like cells, hyphae and chlamydospores of Aureobasidium pullulans. Exp. Mycol. 1985, 9, 230-240. [CrossRef]

209. Crist, R.H.; Oberholser, K.; Shank, N.; Nguyen, M. Nature of bonding between metallic ions and algal cell walls. Environ. Sci. Technol. 1981, 15, 1212-1217. [CrossRef]

210. Bhatti, H.N.; Hamid, S. Removal of uranium (VI) from aqueous solutions using Eucalyptus citriodora distillation sludge. Int. J. Environ. Sci. Technol. 2014, 11, 813-822. [CrossRef]

211. Navarro, A.E.; Lim, H.; Chang, E.; Lee, Y.; Manrique, A.S. Uptake of Sulfa Drugs from Aqueous Solutions by Marine Algae. Sep. Sci. Technol. 2014, 49, 2175-2181. [CrossRef]

212. Chu, K.H. Improved fixed bed models for metal biosorption. Chem. Eng. J. 2004, 97, 233-239. [CrossRef]

213. Aksu, Z.; Gonen, F. Biosorption of phenol by immobilized activated sludge in a continuous packed bed: Prediction of breakthrough curves. Process Biochem. 2004, 39, 599-613. [CrossRef]

214. Vijayaraghvan, K.; Yun, Y.S. Bacterial biosorbents and biosorption. Biotechnol. Adv. 2008, 26, $266-291$. [CrossRef] [PubMed]

215. Volesky, B. Sorption and Biosorption; BV Sorbex Inc.: Montreal-St. Lambert, QC, Canada, 2004.

216. Adamson, A.W.; Gast, A.P. Physical Chemistry of Surfaces, 6th ed.; Wiley: New York, NY, USA, 1997. 
217. Kyzas, G.Z.; Deliyanni, E.A.; Matis, K.A.; Lazaridis, N.K.; Bikiaris, D.N.; Mitropoulos, A.C. Emerging nanocomposite biomaterials as biomedical adsorbents: An overview. Compos. Interfaces 2018, 25, 415-454. [CrossRef]

218. Park, D.; Yun, Y.S.; Park, J.M. The past, present, and future trends of biosorption. Biotechnol. Bioproc. 2010, E15, 86-102. [CrossRef]

219. Ikehata, K.; Naghashkar, N.J.; El-Din, M.G. Degradation of aqueous pharmaceuticals by ozonation and advanced oxidation processes: A review. Ozone Sci. Eng. 2006, 28, 353-414. [CrossRef]

220. Aksu, Z.; Tunc, O. Application of biosorption for penicillin G removal: Comparison with activated carbon. Process Biochem. 2005, 40, 831-847. [CrossRef]

221. Kapoor, A.; Viraraghavan, T. Fungal biosorption-An alternative treatment option for heavy metal bearing wastewater: A review. Bioresour. Technol. 1995, 53, 195-206.

222. Eccles, H. Treatment of metal-contaminated wastes: Why select a biological process? Trends Biotechnol. 1999, 17, 462-465. [CrossRef]

223. Liu, Y.; Liu, Y.J. Biosorption isotherms, kinetics and thermodynamics. Sep. Purif. Technol. 2008, 61, $229-242$. [CrossRef]

224. De Rome, L.; Gadd, G.M. Use of pelleted and immobilized yeast and fungal biomass for heavy metal and radionuclide recovery. J. Ind. Microbiol. 1991, 7, 97-104. [CrossRef]

225. El-Din, S.M.M.; Noaman, N.H.; Zaki, S.H. Removal of Some Pharmaceuticals and Endocrine Disrupting Compounds by The Marine Macroalgae. Pterocladia capillacea and Ulva lactuca. Egypt. J. Bot. 2017, 57, 139-155.

226. Escapa, C.; Coimbra, R.N.; Nuevo, C.; Vega, S.; Paniagua, S.; García, A.I.; Calvo, L.F.; Otero, M. Valorization of Microalgae Biomass by Its Use for the Removal of Paracetamol from Contaminated Water. Water 2017, 9, 312. [CrossRef]

(C) 2019 by the authors. Licensee MDPI, Basel, Switzerland. This article is an open access article distributed under the terms and conditions of the Creative Commons Attribution (CC BY) license (http://creativecommons.org/licenses/by/4.0/). 